\title{
Metal complex catalysis in a synthesis of pyridine bases
}

\author{
Usein M Dzhemilev, Farid A Selimov, and Genrikh A Tolstikov \\ Institute of Petrochemistry and Catalysis, Bashkortostan Republic Academy of Sciences, and \\ Ufa Scientific Centre, Russian Academy of Sciences 141 Prospekt Oktyabrya, Ufa, 450075, \\ Russia \\ E-mail:ink@anrb.ru
}

\section{Dedicated to Professor Mikhail G. Voronkov on the occasion of his $\mathbf{8 0}^{\text {th }}$ birthday (received 20 Oct 01; accepted 05 Mar 02; published on the web 13 Mar 02)}

\begin{abstract}
The review systematizes for the first time literature data of the last 15 years on a synthesis of pyridine bases including those of natural structure with the use of metal complex catalysts. The catalyzed by complexes of transition metals $(\mathrm{Co}, \mathrm{Ni}, \mathrm{Pd}, \mathrm{Zr})$ and rare-earth elements reactions of heterocyclization of acetylenes with nitriles, liquid phase condensation of aldehydes with amines, linear and cyclic oligomerization of vinylpyridines with 1,3-dienes and condensation of carbonic acid chloroanhydrides with olefins, acetylenes, tertiary alcohols to give substituted pyridines, quinolines and phenanthrolines of a set structure are considered. The mechanisms of molecule generation of pyridine bases in the presence of metal complex catalysts are discussed, and data on an effect of transition metal nature, initial monomer structure and reaction conditions on a reaction direction of a formation of six-membered nitrogen heterocycles are listed.
\end{abstract}

Keywords: Catalysis, metal complex, synthesis, pyridine bases

\section{Contents}

1. Introduction

2. Heterocyclization of acetylenes with nitriles catalyzed by cobalt complexes

3. Liquid-phase condensation of carboxylic chloroanhydrides with amines in the presence of Lewis acids

4. Pyridine synthesis by liquid-phase condensation of aldehydes with $\mathrm{NH}_{3}$ under the effect of metal complex catalysts

5. Synthesis of cycloalkenyl- and alkatrienylpyridine by codimerization of vinylpyridines with 1,3-dienes catalyzed by $\mathrm{Zr}$ and $\mathrm{Ni}$ complexes

6. The other methods for a synthesis of pyridines in the presence of metal complex catalysts 
7. Rare-earth element complexes in a synthesis of quinolines, phenanthridines and phenanthrolines

\section{Introduction}

More than 150 years passed from the moment of a discovery of simple pyridine, but a limited assortment of pyridine bases is produced in a commercial scale so far due to the absence of universal and commercially efficient methods of a synthesis of the latters. A development of prospective synthetic methods to produce pyridines including those of complex structure will allow to make the latters more available and, hence, pyridine bases will be widely used in industry.

At present the commercial methods to gain pyridines, such as, 2-methyl-5-ethyl- and 2methylvinylpyridines initiating from acetaldehyde and ammonia with the use of heterogeneous Co-containing catalysts are known together with the classic laboratory methods of pyridine synthesis based on the use of Skraup, Doebner-Miller and Friedlaender reactions.

A sufficient hitch in a field of a synthesis of pyridine bases was observed in 1973, when Japanese researchers showed a possibility to give substituted pyridines in one step via a heterocyclization of two molecules of acetylenes with acetonitriles in the presence of catalytic amount of cobalt complexes. Later this reaction was studied in detail by German authors, particularly, Boennemann and collegues, and prospects of the use of the reaction in a synthesis of pyridine bases of various structure, including vitamines of pyridine series were shown.

It should be noted the application of metal complex catalysts in pyridine chemistry allowed to develop a series of perspective for commercial realization methods of their synthesis, including di- and tricyclic nitrogen heterocycles including pyridine rings - quinolines, naphthyrididines and phenanthrolines by heterocyclization of carbonyl compounds with amines.

As a result for the last years a sufficient data material concerning the application of metal complex catalysts in a synthesis of pyridine bases was accumulated in the world literature and scattered about the numerical papers, patents and thesises.

Hence, the necessity appeared to systematize the literature data on a synthesis of pyridine bases with the use of homogeneous metal complex catalysts. The authors paid a special attention to the discussion and critical analysis of publications by the foreign and native researchers for the last 10-15 years concerning the application of metal complex catalysts in a synthesis of pyridine bases by heterocyclization of acetylenes with nitriles, carbonyl compounds with amines, and chloroanhydrides of carboxylic acids with amines under the effect of Lewis acids.

The numerical publications concerning functionalization of pyridines and their derivatives in the presence of metal complex catalysts were not discussed in the review due to the limited volume. 


\section{Heterocyclization of acetylenes with nitriles catalyzed by cobalt complexes}

The first papers on a possibility to carry out catalytic trimerization in benzene or cyclooctatetraene in the presence of low valence cobalt or nickel complexes appeared at the beginning of 60's. ${ }^{1-3}$ Metallacyclopropenes 1 or metallacyclopentadienes 2 were supposed by the authors to be key intermediates in these reactions. ${ }^{4-6}$

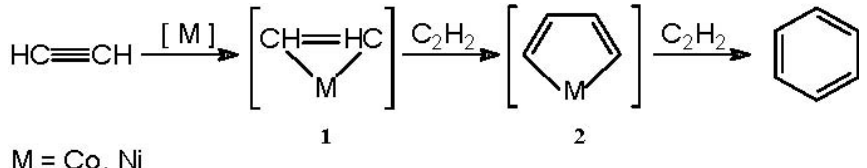

The paper $^{7}$ confirmed acetylene trimerization proceeded via a step of a formation of mctallocyclic intermediates, the interaction of bis(dibenzylidene)palladium with dimethyl ester of acetylenedicarbonic acid was shown to give palladacyclopentadiene 3 , the further reaction of the latter with dimethyl ester of acetylenedicarbonic acid led to the formation of hexamethyl ester of mellitic acid 4. As a result, metallacyclopentadiene formed from acetylene and transition metal complex was stated by the authors ${ }^{7}$ to be catalytically active intermediate in cyclization reactions.

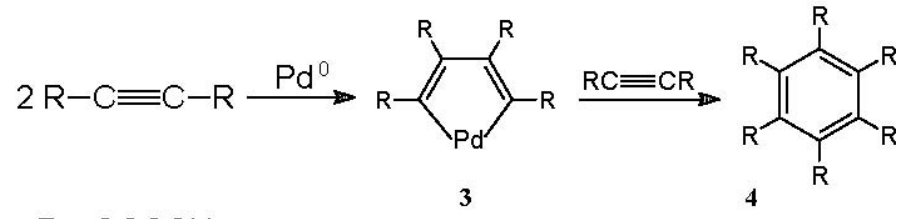

$\mathrm{R}=\mathrm{COOCH}_{3}$

According to the methodology, ${ }^{7}$ platinacyclopentadiene complexes were isolated and characterized together with palladacyclopentadienes. 7,8

Later a series of cobalt metal cycles $\mathbf{5}$ and $\mathbf{8}$ was studied, the reaction of the latters with acetylenes was shown to give substituted benzene derivatives $\mathbf{6 , 7}$ and 9., ${ }^{9,10}$

Then cobalt compounds were found to have the highest activity in cyclization reaction in a series of transition metal complexes studied. ${ }^{11,12}$
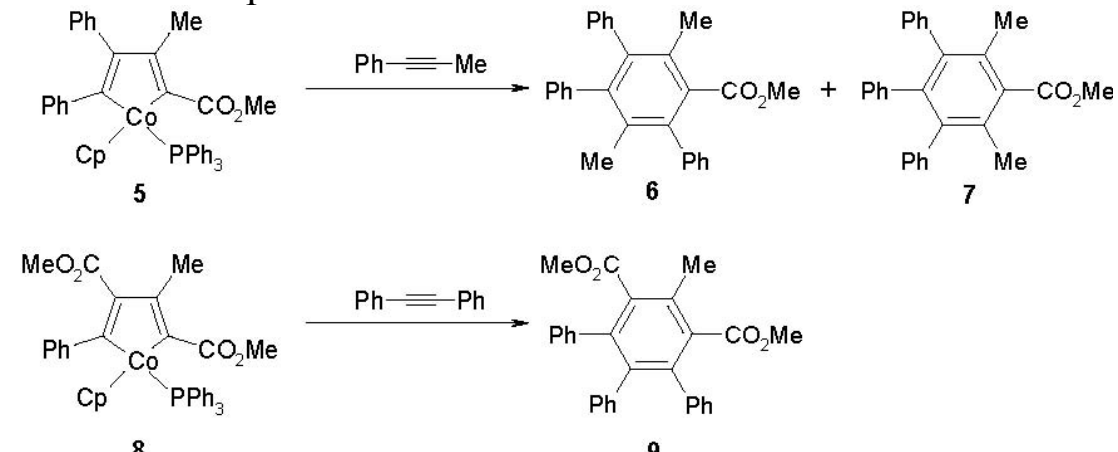

For example, the reaction of $\left(\eta^{5}\right.$-cyclopentadienyl)bis(triphenylphosphine)cobalt 10 with diphenylacetylene gives cobaltacyclopentadiene 12, under reaction conditions the latter includes heterocumulene on $\mathrm{M}-\mathrm{C}$ bond to give heterocyclic compound. An interaction of $\mathbf{1 2}$ with carbon disulfide leads to a formation of 3,4,5,6-tetraphenyldithiopyron-2 13 in $10 \%$ yield. $^{12}$

Thus, at the beginning of 70's cobalt-containing complexes were stated to be the most active 
and selective catalysts of acetylene cyclomerization leading to the formation of substituted benzenes of the set structure. 3,13

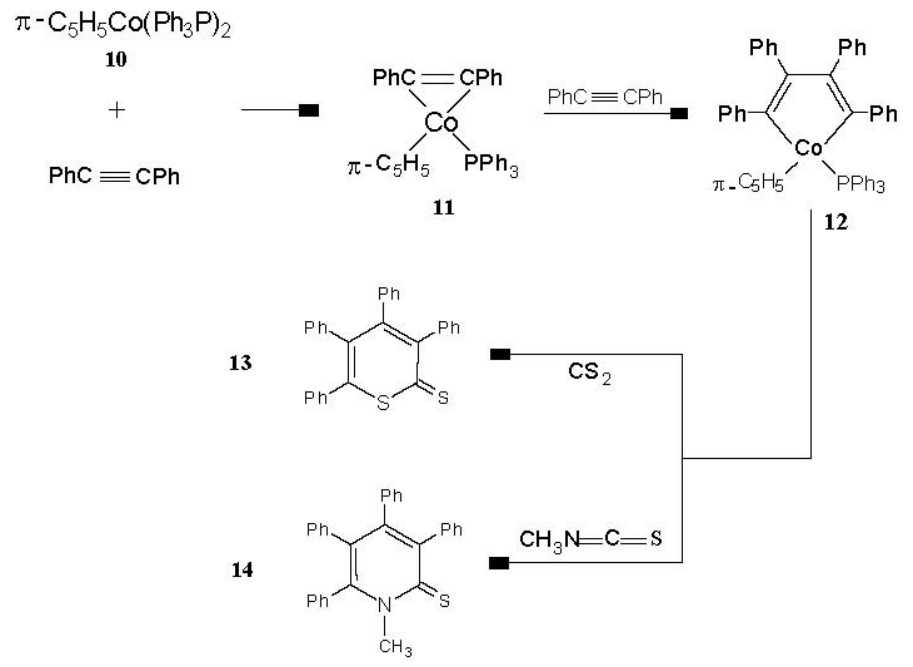

Thus, to the beginning of 1973 the researchers from Japan and Germany have realized the reactions of acetylene cyclocotrimerization with nitriles catalyzed by highly active Co complexes to give substituted pyridines under mild conditions.

The first experiments on the common acetylene heterocyclization with nitriles in the presence of cobalt-containing catalysts showed the prospect of the application of the reaction to give substituted pyridines $15^{12,14-17}$

To some extent the results obtained were predicted, as in the reactions of one of the $-\mathrm{C}=\mathrm{C}$ groups in acetylenes was changed for nitrile group $-\mathrm{C}=\mathrm{N}$. A formation of benzene $\mathbf{1 6}$ was observed in the reactions in the absence of nitrile (RCN).

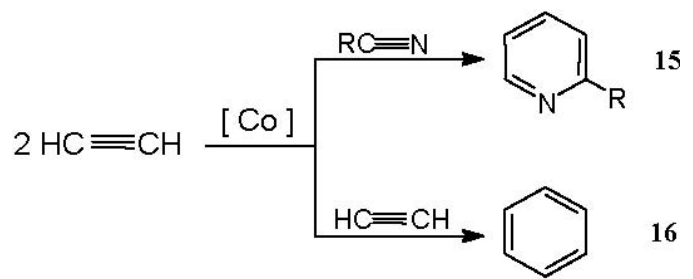

A formation of pyridine derivatives was stated experimentally ${ }^{18,20}$ to be preferable under the conditions favorable for the competitive proceeding of the both reactions. The data are in a good agreement with quantum-mechanical calculations, ${ }^{21}$ the latters confirm acetylene heterocyclization with nitriles is energetically more favorable than acetylene homocyclotrimerization.

The first paper on a synthesis of substituted pyridines by acetylene heterocyclization with nitriles $\mathrm{RC}=\mathrm{N}\left(\mathrm{R}=\mathrm{CH}_{3}, \mathrm{Ph}, \mathrm{PhCH}_{2}\right)$ in the presence of Co-containing complex catalysts was published by Japanese researchers. ${ }^{12} \alpha$-Picoline 17 was shown for the first time to be formed in $23 \%$ yield during heating $\left(\sim 70{ }^{\circ} \mathrm{C}\right.$, benzene) of acetonitrile and acetylene for 7 hours in the presence of $\left(\eta^{5}\right.$-tetraphenylcyclopentadienyl)(triphenylphosphine)cobalt. 


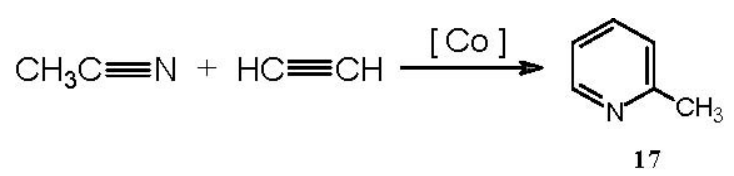

Under similar conditions diphenylacetylene and 1,4-dimetoxy-2-butin with acetonitrile give 2-methyl-3,4,5,6-tetraphenylpyridine 18 and 2-methyl-3,4,5,6-tetrametoxymethylpyridine 19 in 38 and $8 \%$ yield, respectively.

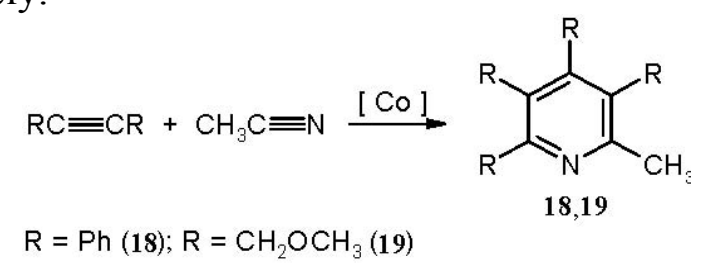

Under the conditions mentioned mono-substituted acetylenes react with acetonitrile to give the mixture of regioisomeric 2-methyl-3,6-dialkyl- and 2-methyl-4,6-dialkylpyridines 20 and 21 respectively. ${ }^{12}$

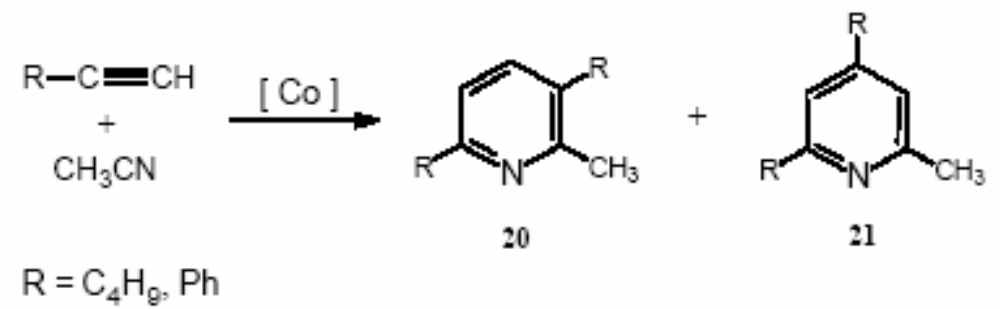

The low yield of pyridine bases and multistep synthesis of the initial catalysts are the considerable shortcomings of the method developed. ${ }^{12}$ Really, complex $\left(\eta^{5}\right.$ tetraphenylcyclopentadienyl)(triphenylphosphine)cobalt used by the authors is synthesized from difficult initial reagents in several steps in $10 \%$ yield. $^{22}$

In the same 1973 Japanese authors have supposed the formation of pyridine molecules 18 proceeded via a step of a formation of cyclic metal complex intermediates $\mathbf{1 1}$ and $\mathbf{1 2}$ when they discussed a mechanism of nitrile cyclocotrimerization. ${ }^{14}$

In the authors' opinion, cobaltacyclopentadienes $\mathbf{1 2}$ formed from cobaltacyclopropenes $\mathbf{1 1}$ and initial acetylenes are the key intermediates in the above reactions. ${ }^{14,22}$

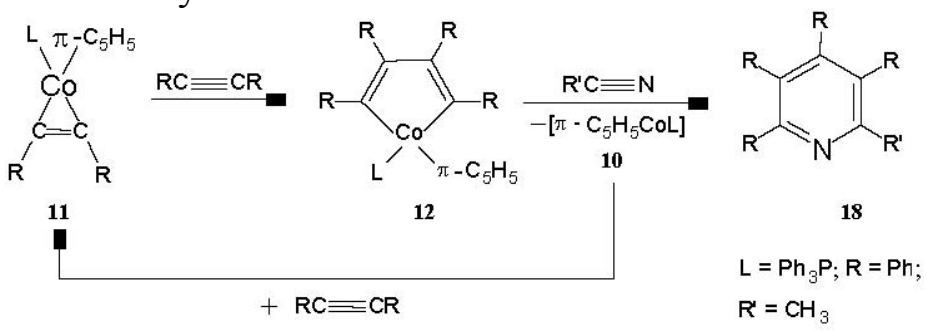

The subsequent reaction of $\mathbf{1 2}$ with initial nitriles led to the formation of the corresponding substituted pyridines 18.

The reaction of acetylene cyclotrimerization with nitriles in the presence of catalyst $\mathrm{CpCo}\left(\mathrm{PPh}_{3}\right)_{2} 10$ was studied in detail, and a series of five-membered metal cycles $\mathbf{2 4}$ and cobalt acetylene complexes $\mathbf{2 2}$ and $\mathbf{2 3}$ responsible for the formation of pyridine molecules were isolated from the reaction mixture and characterized. ${ }^{9,23-27}$ 


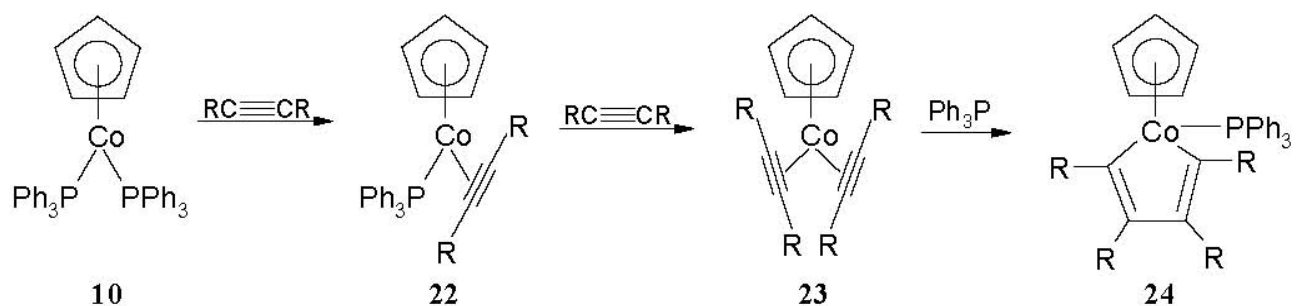

The intensive investigations in this field allowed to produce and identified a series of cobaltacyclopentadiens $\mathbf{2 5}$ having various substituents in a five-membered cycle. A stoichiometric reaction of $\mathbf{2 5}$ with nitriles leads to the formation of asymmetrically substituted pyridines 26, this is confirmed by the mechanism of the pyridine formation proposed by the authors. ${ }^{28}$

The mentioned above papers on formation, isolation and identification of cobalt metal cycles, and inclusion of the latters to the subsequent reactions of cyclization with nitriles ${ }^{12,14,28}$ played a significant role in understanding of a mechanism of the reaction and in a successful development of the direction in the pyridine chemistry.

It should be noted, that presently cobaltacyclopentadiene metal cycles are indisputable key intermediates in the above reactions of cyclocotrimerization.

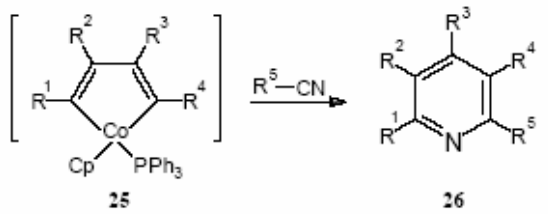

Approximately at the same time $\mathrm{H}$ Boennemann and collegues have found that the reaction of acetylene cyclotrimerization with nitriles might be catalyzed by low valence Co complexes formed in situ by the reduction of compounds of two- or trivalent cobalt with the use of $\mathrm{NaBH}_{4}$, $\mathrm{BuLi}, \mathrm{EtMgX}, \mathrm{Hg}, \mathbf{~ L i}, \mathbf{L i H}, \mathrm{LiAlH}_{4}$, etc. In that case isomeric pyridines $\mathbf{2 7}$ and $\mathbf{2 8}$ are afforded in high yields ${ }^{16}$ from nitriles $\mathrm{RC} \equiv \mathrm{N}\left(\mathrm{R}=\mathrm{CH}_{3}, \mathrm{C}_{2} \mathrm{H}_{5}, \mathrm{CH}=\mathrm{CH}_{2}, \mathrm{Ph}, \mathrm{PhCH}_{2}\right)$ and acetylenes $\mathrm{R}^{\prime} \mathrm{C} \equiv \mathrm{CH}$ $\left(\mathrm{R}^{\prime}=\mathrm{CH}_{3}, \mathrm{C}_{5} \mathrm{H}_{11}, \mathrm{Ph}, \mathrm{PhCH}_{2}\right)$ in contrast to the experiments, where complexes prepared beforehand are used as catalysts.

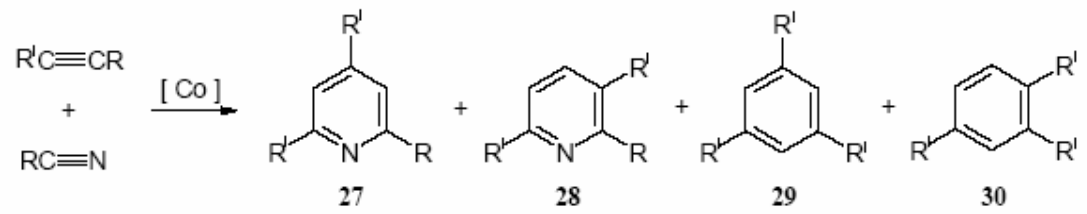

Thus for example, cyclocotrimerization of propionitrile with methylacetylene under the effect of Co-containing catalyst $\left(\mathrm{CoCl}_{2} / \mathrm{BuLi}\right)$ proceeds to give isomeric trialkylpyridines 27 and 28 in $71 \%$ yield.

2,2'-Dipyridyl was produced in 95\% yield in a heating of 2-cyanopyridine with acetylene (toluene, $\left.120{ }^{\circ} \mathrm{C}, 10 \mathrm{~h}\right)$ in the presence of a catalyst $\left(\eta^{5}\right.$-cyclopentadienyl $)\left(\eta^{4}-1,5-\right.$ cyclooctadiene)cobalt(II). ${ }^{29}$ Under similar conditions a mixture of 2,4-dimethyl-6-(pyridyl2)pyridine 31 and 2,5-dimethyl-6-(pyridyl-2)pyridine 32 was produced in 72:28 ratio in 91\% yield. 


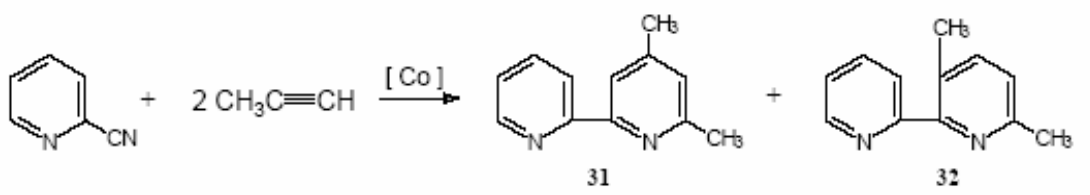

According to the above reaction, $\alpha, \omega$-dipyridylalkanes 33 may be easily produced initating from $\alpha, \omega$-dicyanoalkanes, acetylene and Co-containing catalysts (toluene, $140-150{ }^{\circ} \mathrm{C}$ ). ${ }^{29}$

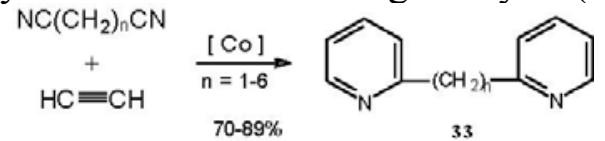

Later informations (preferably patents) on cyclocotrimerization of acetylenes with nitriles in the presence of salts of two- and trivalent cobalt, and prepared beforehand low-valence cobalt complexes, such as, $\left(\eta^{1}\right.$-cyclooctenyl $)\left(\eta^{4}-1,5\right.$-cyclooctadiene $) \mathrm{Co}(\mathrm{I}), \quad$ (methylheptadienyl)(butadiene)Co(I) or $\left(\eta^{5}\right.$-cyclopentadienyl $)\left(\eta^{4}-1,5\right.$-cyclooctadiene $) \operatorname{Co}(\mathrm{I})$ appeared in the world literature. $^{30-32}$ The reaction of methylacetylene with acetonitrile in the presence of (methylheptadienyl)(butadiene)Co(I) leads to the formation of 2,4,6- and 2,3,6-colidines in 43\% and $19 \%$ yields, respectively. It should be noted that the prepared beforehand low-valence cobalt complexes are low stable and hardly prepared, that limits their wide use.

The patent ${ }^{17}$ describes a synthesis of substituted pyridines by reaction of cyclocotrimerization of nitriles $\mathrm{RCN}(\mathrm{R}=$ alkyl, aryl, alkenyl) with acetylene or dialkylacetylene in the presence of heterogeneous catalysts (metallic cobalt or $\mathrm{Co}_{2} \mathrm{O}_{3}$ ). Alkyl- and arylphosphines, substituted $\beta$ diketones or poly(pyrazoline)borates are used as ligands in these reactions. In spite of strict conditions of the reaction $\left(200-350{ }^{\circ} \mathrm{C}, 105 \mathrm{~atm}\right.$.), yields of substituted pyridines are rather low in these experiments. When $\mathrm{Co}^{+2}$-dihydrobis(1-pyrazoline)borate was used as a catalyst, yield of 2-methylpyridine consisted of $44 \%$. The higher yields of substituted pyridines are managed to be produced with the use of cobalt compounds put on zeolites. ${ }^{33}$ The catalysts showed a high selectivity with respect to the target pyridines. A cyclocotrimerization of phenylacetylene with acetonitrile gives a mixture (80:20) of 2-methyl-4,6-diphenyl- and 2-methyl-3,6diphenylpyridines 34 and 35 in total $60-70 \%$ yield.

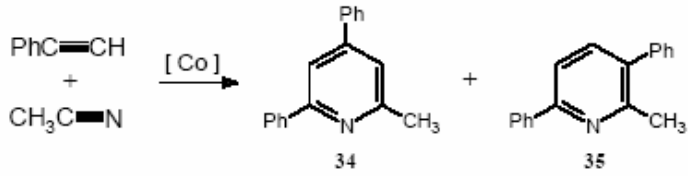

A cyclocotrimerization of benzonitrile with $\alpha, \omega$-diacetylene hydrocarbons, and $\alpha, \omega$-dinitrile with diphenylacetylene leading to the formation of complex substituted pyridines $\mathbf{3 6}$ and $\mathbf{3 7}$ is a significant invention in a synthesis of pyridine bases. ${ }^{15}$

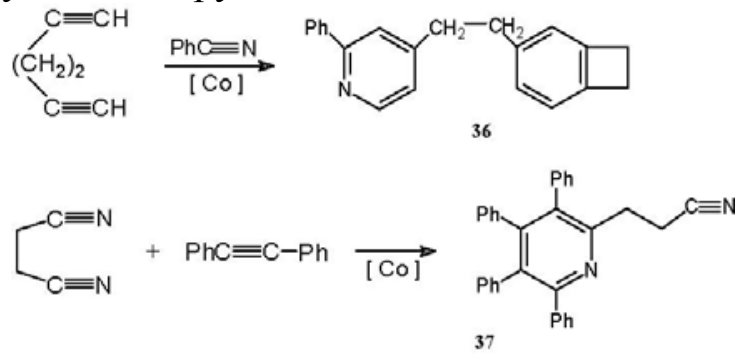


During the comparison of catalytic activity and selectivity of catalysts used in the reaction of heterocyclization the authors in most cases gave preference to the prepared beforehand cobalt complexes. ${ }^{34-38}$ However later the most research centres refused from the application of specially prepared complexes as catalysts due to the hard preparation and passed to more available cobaltocene $\mathrm{Cp}_{2} \mathrm{Co},{ }^{39}$ and a series of other Co-containing catalysts, the base of which is "CpCo". ${ }^{40,41}$

A cyclotrimerization of acetylene with benzonitrile in the presence of the mentioned catalysts gave 2-phenylpyridines 38. The authors systematically studied an effect of functional groups in initial nitriles on the direction and total yield of the reaction products. ${ }^{42,43}$

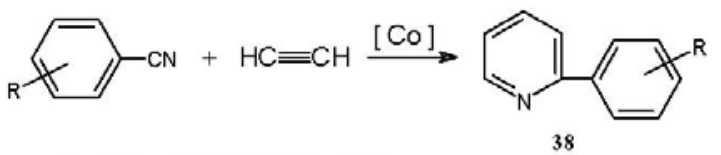

$$
\mathrm{R}=\mathrm{CH}_{3}, \mathrm{Cl}, \mathrm{Br}, \mathrm{OC}_{2} \mathrm{H}_{5}, \mathrm{NO}_{2}
$$

Developing the previous research work, ${ }^{15}$ American researchers synthesized a series of bicyclic pyridines 39 by the interaction of $\alpha, \omega$-diacetylenes with nitriles in the presence of catalytic amount of $\left(\eta^{5}\right.$-cyclopentadienyl)cobalt dicarbonyl. ${ }^{44}$

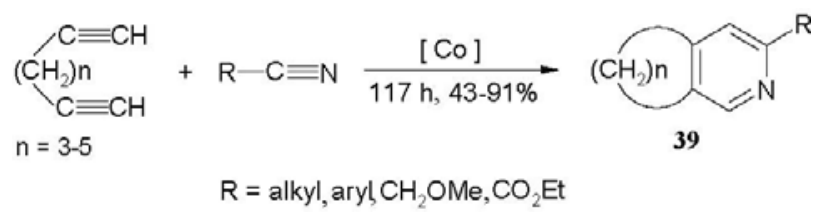

Nitriles containing electron-attracting substituents form pyridines in very low yields. This fact may be explained by the reaction of cyclocotrimerization begins from the formation of cobaltacyclopentadiene 40, then nitrile molecule is coordinated due to the unshared pair of electrons on the central atom of the catalyst and then pyridine molecule is formed. Nitriles with electron-attracting substituents cannot compete with acetylene for the ligand place on the catalyst central atom, that leads to the formation of substituted benzenes. When nitrile is introduced to the sterically less hindered $\mathrm{Co}-\mathrm{C}$ bond, $\mathrm{R}^{2} \mathrm{C} \equiv \mathrm{N}$ nitrogen passes to $\alpha$-position to Co $\mathbf{4 1}$, and substituted pyridines $\mathbf{4 3}$ are formed from the complex $\mathbf{4 2}$.
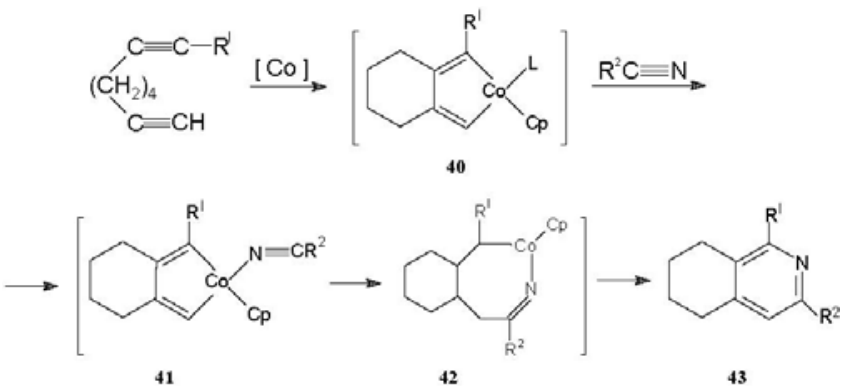

5,6,7,8-Tetrahydroquinolines are formed by "one-pot" method under the above reaction conditions. ${ }^{45}$

The reaction of heterocyclization of disubstituted acetylenes with $\alpha, \omega$-acetylenenitriles leading to bicyclic pyridines $\mathbf{4 4}$ and $\mathbf{4 5}$ is of special interest. ${ }^{46}$ 


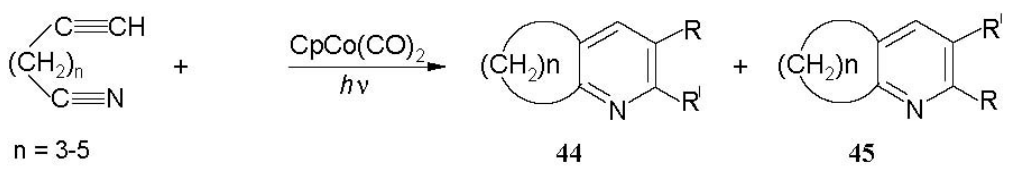

In the middle of 70's and beginning of 80's a number of licence material on a synthesis of 2substituted pyridine bases $\mathbf{4 6}$ in the presence of cobaltocene as highly active and selective catalyst was published. ${ }^{4-49}$ Yield of the target products is rather high $(\sim 90 \%)$, but benzene in $9-$ $10 \%$ is formed as a side product in each experiment.

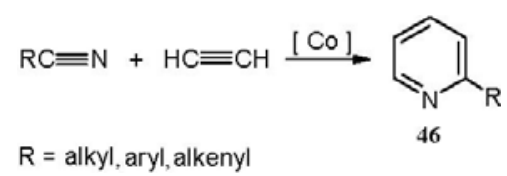

A reaction of cyclocotrimerization of acetylenes with chiral nitriles was used by Italian researchers for the synthesis of optically active pyridines $47 . .^{50,51}$

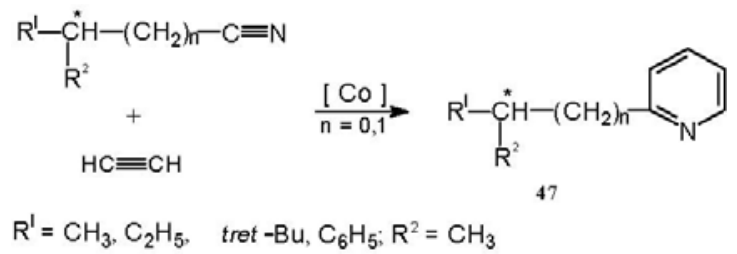

The research works concerning a synthesis of practically useful aminopyridines initiating from aminonitrile and acetylenes attract an attention. ${ }^{34,48,49}$ The interaction of phenylacetylene with cyanamide gives a mixture of 2-amino-4,6- 48 and 2-amino-3,6-diphenylpyridines 49 in one step in $87 \%$ yield.

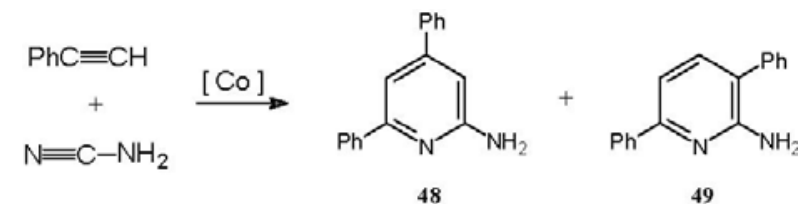

A realization of the catalyzed by Co complexes reaction of alkylthiocyanates with acetylene allowed to develop a method for a synthesis of alkylthiopyridines, ${ }^{34,52}$ the latters are hardly available so far. ${ }^{53}$ Yield of the reaction products 50-52 depends mainly on a ratio of initial monomers and reaction conditions.

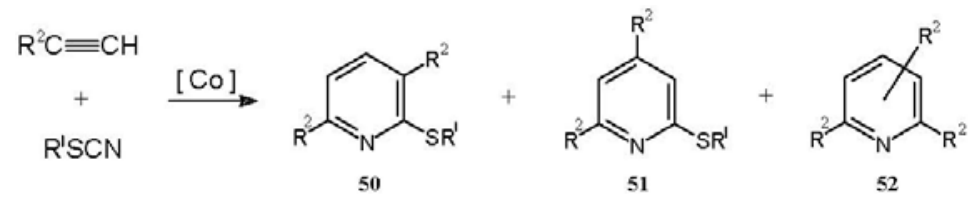

From the beginning of 70's the researchers carry out a search of the other transition metals able to proceed the reaction of cyclotrimerization of acetylenes with nitriles. On the basis of the studies it was stated that there are no catalysts equal in activity and selectivity to those of Cocontaining. The rhodium catalysts are inferior to cobalt complexes in a reaction of cyclocotrimerization. ${ }^{54,55}$ The development of more effective and selective Co-containing catalysts for these reactions attracts a special attention. 
For example, the paper $^{56}$ proposes the suitable method to obtain cyclopentadienyl cobalt complexes active in the reaction of cyclocotrimerization of acetylenes with nitriles. Cobalt salts are introduced to the reaction with activated magnesium and anthracene or magnesium adducts with anthracene in the presence of complex-forming ligands - halogen-hydrocarbons - in THF or diglyme. The authors ${ }^{56}$ produced cobaltocene in $63 \%$ yield and phenylcyclopentadienyl-Cocyclooctadiene-1,5 in $40 \%$ yield.

The other approach to the synthesis of the above catalytic complexes is based on the direct reduction of cobalt salts in the presence of complex-forming ligands with the use of $\mathrm{AlEt}_{3}$ or $\mathrm{NaBH}_{4}{ }^{57}$ Yield of cobalt complexes consists of $70 \%$.

$\mathrm{P} \mathrm{Hardt}^{58}$ proposed the improved method to give cobaltocene based on the reaction of cyclopentadienylsodium with anhydrous $\mathrm{CoCl}_{2}$ in acetonitrile. Yield of cobaltocene consists of no less than $80 \%$ under the described conditions.

The synthesis of pyridines by cyclocotrimerization of acetylenes with nitriles in the presence of Co-containing catalysts modified by bioorganic compounds gave interesting results. ${ }^{59,60}$ The choice of boron-containing ligands was not accidental, as the latters promote a proceeding of cyclocotrimerization under milder conditions and in high yields of target pyridines.

The research works to rise the catalytic activity of organocobalt catalysts were carried out by Japanese researchers. ${ }^{61}$ The object was attained by the application of $\left(\eta^{5}\right.$ methoxycarbonylcyclopentadienyl $)\left(\eta^{4}\right.$-cyclooctadiene $)$ Co and $\left(\eta^{5}\right.$-methoxycarbonylcyclopentadienyl $)\left(\eta^{4}\right.$-cyclooctatetraene $)$ Co as catalysts. ${ }^{62}$

Italian researchers proposed to use freshly sublimated metal cobalt, that is condensed directly to the reaction mixture, as catalysts for cyclocotrimerization. ${ }^{63}$ Yields of substituted pyridines according to this method consist of more than $80 \%$.

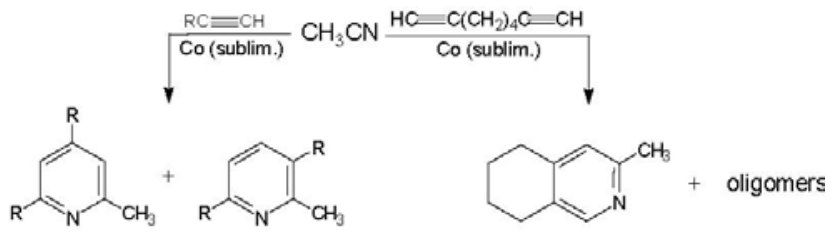

For higher activity and selectivity of the catalyst developed Italian researchers proposed to use metallic cobalt 53 solvated with arenes. ${ }^{64,65}$

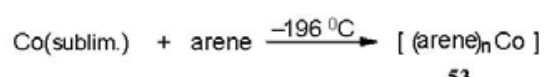

53

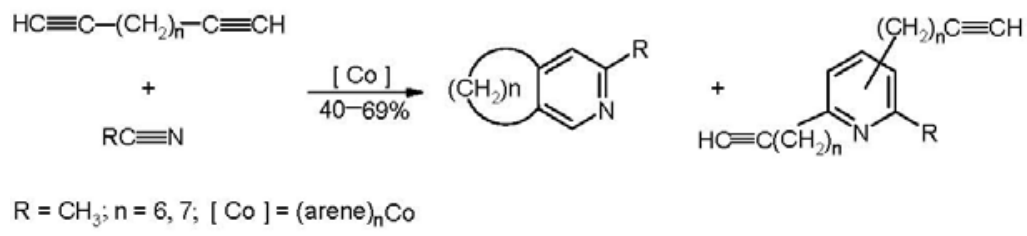


According to the licence literature ${ }^{66,67}$ American researchers carried out a synthesis of bicyclic pyridines by the interaction of $\alpha, \omega$-diacetylenes with nitriles in the presence of a catalyst $\mathrm{CpCo}(\mathrm{CO})_{2}$. The reactions said above were carried out in a liquid-phase in equimolar ratio of acetylene and nitriles in toluene, xylene or n-octane in $47-81 \%$ yield of the target products. The chosen catalytic system allows to include functionally substituted $\alpha, \omega$-diacetylenes to the reaction.

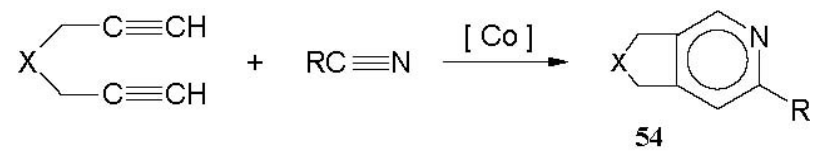

Dipropargyl amines ${ }^{68,69}$ containing gem-dialkyl groups easily enter to the analogous transformations in the presence of catalytic system $\mathrm{CoCl}_{2} / \mathrm{Mn}$. The presence of gem-dialkyl groups in a molecule of initial diacetylene allowed to rise yield of dihydropyrrolopyridines 55 up to $90-98 \%$ and to decrease reaction temperature to $80{ }^{\circ} \mathrm{C}$.

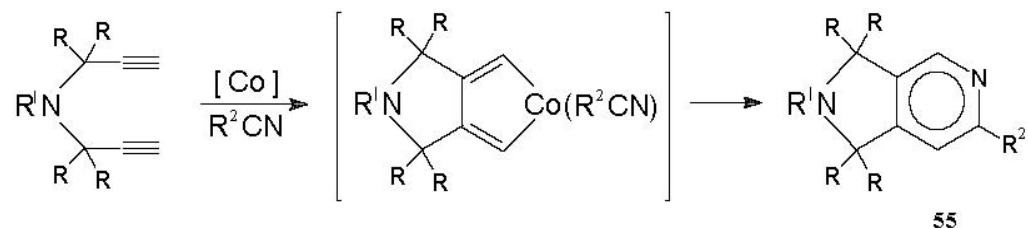

$$
\mathrm{R}, \mathrm{R}^{\prime}=\text { alky } ; \mathrm{R}^{2}=\text { alkyl, aryl }
$$

It should be noted that the above dipropargyl amine reacts with $\alpha, \omega$-dinitriles not only in the presence of Co-containing catalysts, but in the presence of phosphine nickel complex $\mathrm{Ni}\left[\mathrm{P}\left(\mathrm{OPr}^{\mathrm{i}}\right)_{3}\right]_{4}$ to give dihydropyrrolopyridine $56 .{ }^{68}$
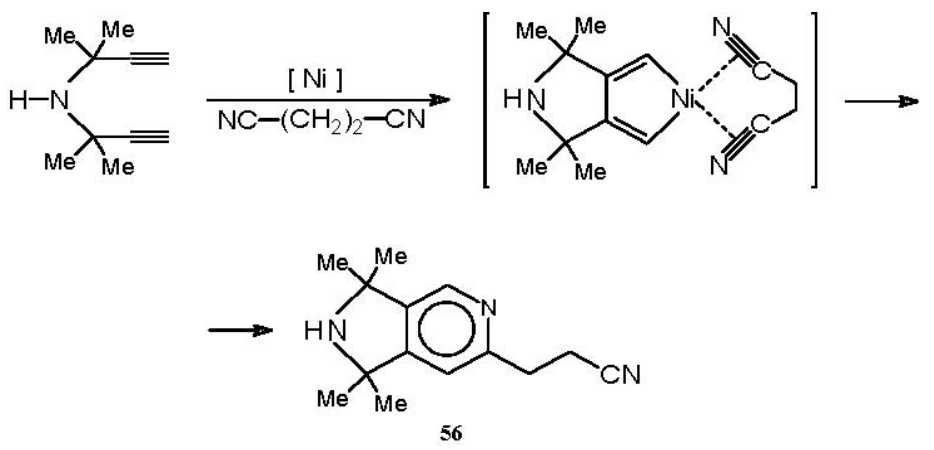

The research works concerning the studies on cyclocotrimerization of acetylene with nitriles for a synthesis of complex pyridine bases, including natural compounds are of great theoretical and practical interests. For example, a cyclocotrimerization of the corresponding diacetylenes with nitriles catalyzed by cyclopentadienyl cobalt complexes $\left(\mathrm{CpCo}(\mathrm{CO})_{2}\right)$ allowing to obtain compounds with i-naphthyridine $57^{70}$ or 2 -azaanthracene 58 skeleton in one step. ${ }^{36}$ 


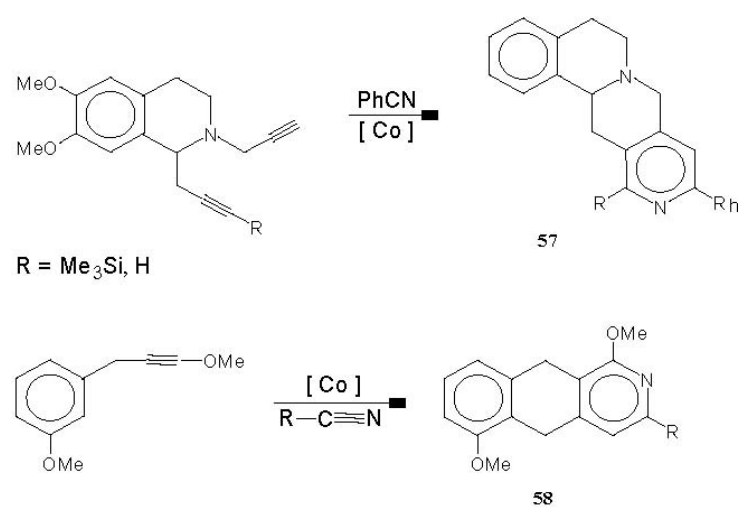

The application of dipropargyl ether as initial diacetylene makes regioselective synthesis of vitamin $\mathrm{B}_{6} \mathbf{5 9}$ to be possible practically in three technologic steps. ${ }^{36,71}$
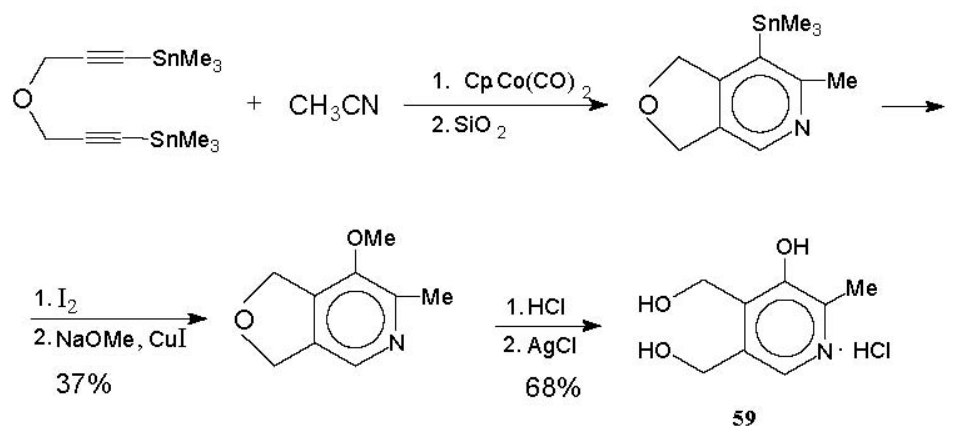

The analogous approach to a synthesis of vitamin $\mathrm{B}_{6}$ from silylated dipropargyl ether was proposed by the authors. ${ }^{72}$ Cobaltocene was used as a catalyst, and acetonitrile was used as initial reagent and a solvent.
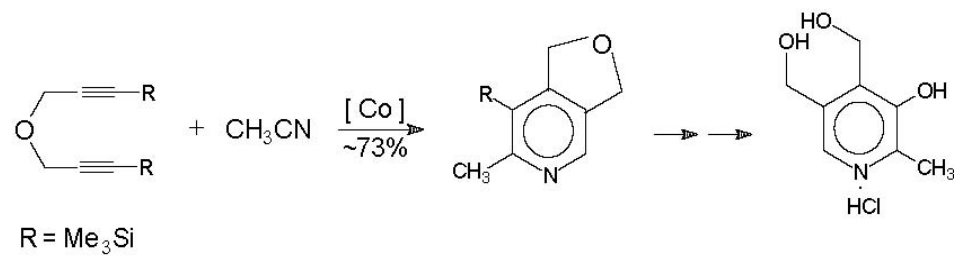

According to the above examples, substituted pyridines may be generated by the reaction of nitriles with mono- or disubstituted acetylenes in the presence of metal complex catalysts. In 1983 the first paper $^{73}$ on cyclocodimerization of $\alpha, \omega$-cyanoacetylenes to bicyclic pyridines $\mathbf{6 0}$ under the effect of two-component system consisting of $\mathrm{Co}$ (2-ethylhexanoate) $)_{2}$ and $\mathrm{AlEt}_{3}$ in a molar ratio 1:3 was published. The total absence of benzene derivatives resulted from acetylene homocyclotrimerization is a peculiarity of the reaction. The authors ${ }^{73}$ suppose that nitrile and acetylene groups of the initial $\alpha, \omega$-cyanoacetylenes under reaction conditions enter a coordination sphere of a metal and hinder an approach to a central atom of a catalyst simultaniously of three acetylene molecules and their activation, and hence, a formation of benzene derivatives. A formation of pyridines from $\alpha, \omega$-cyanoacetylenes is appeared to be energetically more advantageous process than a formation of benzene molecules. 


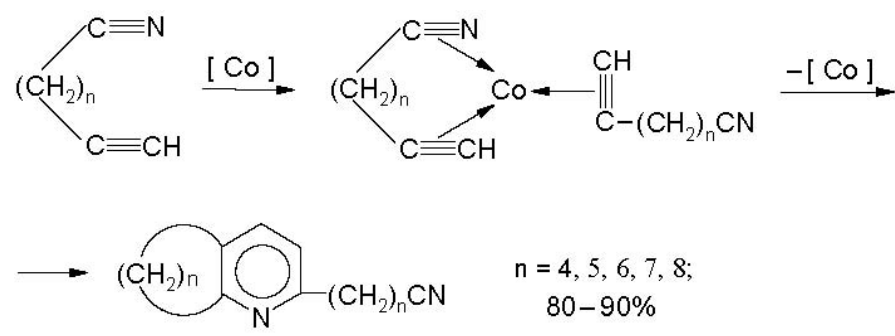

60

All attempts to carry out homodimerization of oxygen-containing cyanoacetylenes were unsuccessful. ${ }^{74}$ In all experiments independently of changes in reaction conditions and of a nature and a concentration of a catalyst homocyclotrimerinations products of initial cyanoacetylenes to the corresponding trisubstituted benzenes were generated in unsufficient amount. It may be, oxygen atom in nolecule of $\alpha, \omega$-cyanoacetylenes due to the unshared pair of electrons takes in a formation of coordination sphere of catalyst central atom binding to the approach and coordination of acetylene and nitrile groups simultaneously in initial monomers.

At the same time, cyclocodimerization of oxygen-containing $\alpha, \omega$-cyanoacetylenes with acetylene on a catalytic system consisting of $\mathrm{Co}$ (2-ethylhexanoate) $)_{2}$ and $\mathrm{AlEt}_{3}$ proceeds easily in toluene at $150{ }^{\circ} \mathrm{C}$ and acetylene pressure of $10-15$ atm. to result in a mixture of pyridine 61 and 62 and cyanoethylated derivative of benzyl alcohol $63 .{ }^{74}$

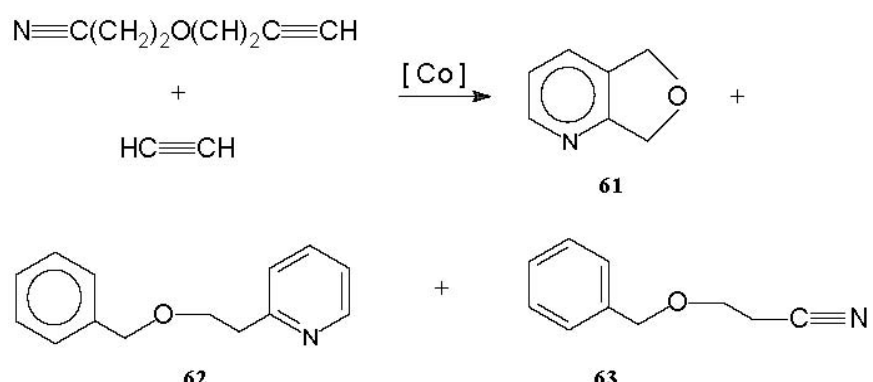

The papers on a catalytic synthesis of the novel type of polyfunctional $\alpha, \omega$-mono- and dipyridines attract an attention. ${ }^{75,76}$ Polyfunctional dinitriles in contrast to simple nitriles were found to react with acetylene only with the use of significant amount of the catalyst (Co:Al:nitrile $=1: 3: 10-20)$ to give the corresponding mono- and dipyridines in high yields $(90 \%)$.

$$
\text { N } \equiv \mathrm{C}\left(\mathrm{CH}_{2}\right)_{2} \mathrm{O}-\left[-\left(\mathrm{CH}_{2}\right)_{2} \mathrm{O}\right]_{n}-\left(\mathrm{CH}_{2}\right)_{2} \mathrm{C} \equiv \mathrm{N} \frac{[\mathrm{Co}]}{\mathrm{CH} \equiv \mathrm{CH}}
$$

The reaction of acetylene derivatives with nitriles under the effect of metal complex preliminarily Co-containing catalysts was shown in the examples to be the most prospective 
method of one-step synthesis of substituted pyridines at present.

\section{Liquid-phase condensation of carboxylic chloroanhydrides with amines in the presence of Lewis acids}

At the end of 70's the first paper ${ }^{77}$ on a synthesis of alkyl-substituted pyridines by a reaction of tbutanol with acetylchloride and gaseous ammonia in the presence of $\mathrm{AlCl}_{3}$ as condensing agent was published. The reaction proceeds unselectively to give a mixture of 2,4,6-trimethylpyridine 64, 4-acetonyl-2,6-dimethylpyridine $\mathbf{6 5}$ and 1,3,6,8-tetramethyl-2,7-naphthyridine $\mathbf{6 6}$ in common $85 \%$ yield.
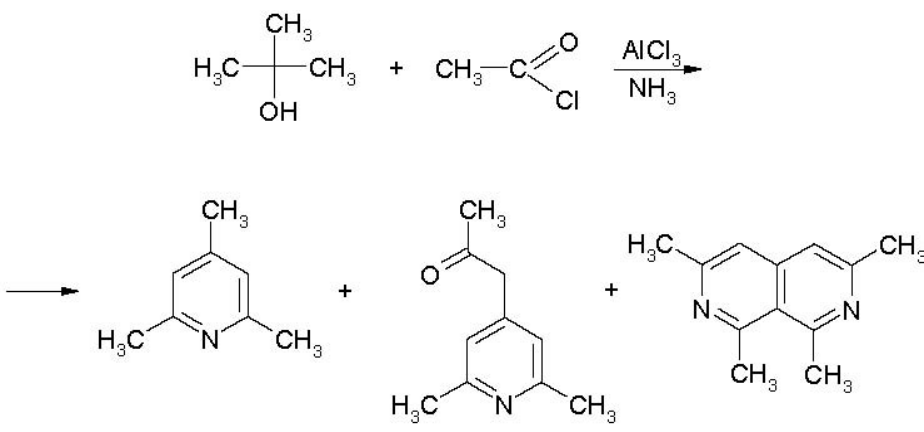

64 65

66

The reaction was studied to state a change of $\mathrm{AlCl}_{3}$ for $\mathrm{ZnCl}_{2}$ allowed to obtain a target product 64 in $95 \%$ and with $100 \%$ selectivity. ${ }^{78,79}$

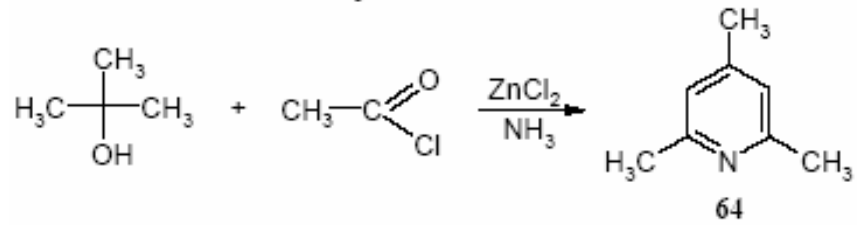

A high selectivity of condensation reaction may be explained by the properties of zinc dichloride, the latter is "milder" Lewis acid and promotes to decrease sufficiently initial monomers directing the reaction to a formation of practically important trimethylpyridine 64 .

As to a mechanism of the reaction developed, the authors suppose alcohol dehydration to isobutylene proceeds firstly, then the latter interacts with acetylchloride to give pyrylium salt 67 , a treatment of the latter by ammonia gives trimethylpyridine $\mathbf{6 4}$ according to Scheme below:

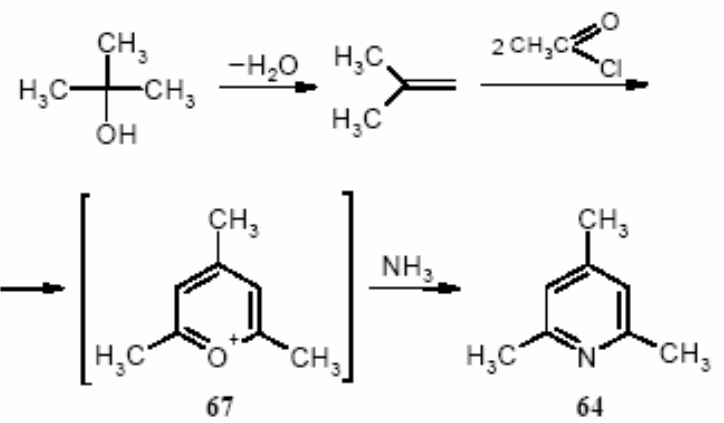


The supposition was confirmed experimentally by changing t-butanol for isobutylene. ${ }^{80,81}$ The reaction was supposed to result in 2,4,6-trimethylpyridine 64 in high yield (88\%). The studies in this direction was prospective to give alkyl-substituted pyridines from chloroanhydrides of carboxylic acids in the presence of catalyst $\mathrm{ZnCl}_{2}$ and $\mathrm{InCl}_{3}, \mathrm{SnCl}_{4}{ }^{82,83}$

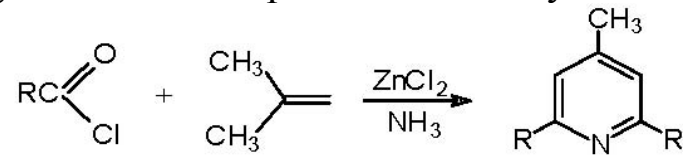

$\mathrm{R}=\mathrm{alkyl}$

The positive results ${ }^{83,86}$ on a synthesis of alkyl-substituted pyridines by the reaction of tertial alcohols and olefins with carboxylic chloroanchydride and $\mathrm{NH}_{3}$ in the presence of Lewis acids allowed to involve ethynylcarbinols, vinylacetylenes and their derivatives to the above reaction. A paper on a formation of triphenylpyridine 68 from chloroanhydride of benzoic acid, phenylacetylene and $\mathrm{NH}_{3}$ in the presence of $\mathrm{SnCl}_{4}$ as a catalyst is appeared to be the precondition for the studies mentioned. ${ }^{84-86}$

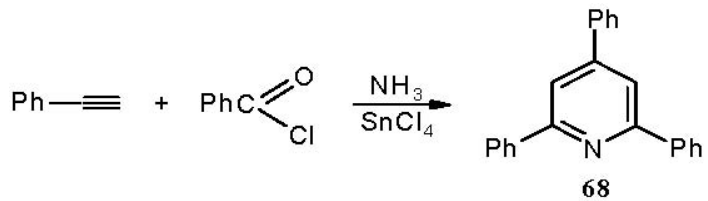

The interaction of dimethylethynylcarbinol with carboxylic chloroanhydrides and $\mathrm{NH}_{3}$ in the presence of $\mathrm{ZnCl}_{2}$ was experimentally shown to give 2-alkyl-4-methylpyridines 69 in high yields $(90 \%)$ and selectivity under mild conditions $\left(40{ }^{\circ} \mathrm{C}\right) .{ }^{87,88}$

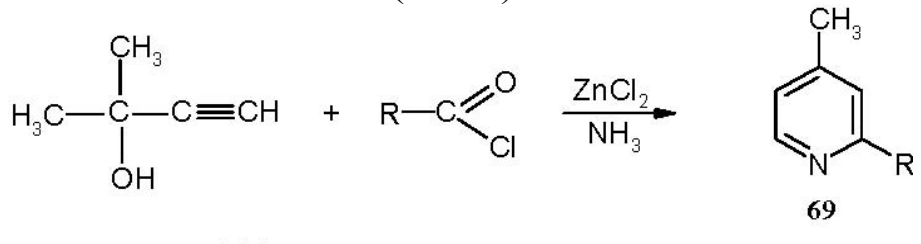

$$
\mathrm{R}=\mathrm{CH}_{3}, \mathrm{C}_{3} \mathrm{H}_{7}, \mathrm{C}_{4} \mathrm{H}_{9}
$$

Under reaction conditions the dehydration of dimethylvinylcarbinol to vinylacetylene, which then interacts with carboxylic chloroanhydride and ammonia in the presence of catalytic amount of $\mathrm{ZnCl}_{2}$ to give 2-alkyl-4-methylpyridine 69 was supposed by the authors ${ }^{87,88}$ to proceeds initially. The condensation of 2-methylvinylacetylene with acetylchloride with a subsequent treatment of the reaction products by $\mathrm{NH}_{3}$ was carried out to confirm the above supposition. ${ }^{89}$ The selective formation of 2,4-dimethylpyridine in 90\% yield confirmed the supposed mechanism of a formation of substituted pyridines via a step of a dehydration of initial dimethylvinylcarbinols to be correct.

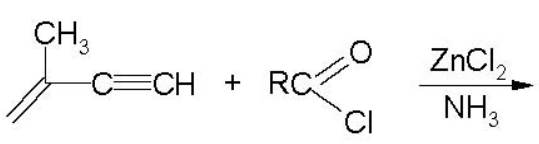

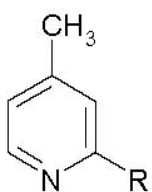

69

The experiments carried out and conclusions drawn ${ }^{87,89}$ open the prospects for the directed 
synthesis of di-, tri- and tetraalkylpyridines. Really, under the conditions obtained the reaction of 1,2-dialkyl-1,3-enines with carboxylic chloroanhydrides leads to only 2,3,4-trialkylpyridines $\mathbf{7 0}$, while an application of 2,4-dialkyl-1,3-enines in high selectivity gives 2,3,4,6tetraalkylsubstituted pyridines $\mathbf{7 1} .^{87}$

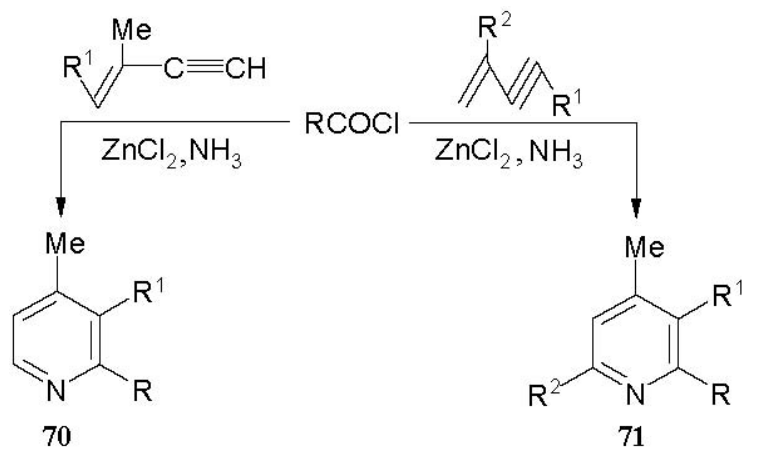

The reaction of ethynylcarbinols, substituted vinyl- and methyleneacetylenes with carboxylic chloroanhydrides and $\mathrm{NH}_{3}$ was found experimentally by the isolation of intermediates to proceed via a step of a formation of pyrylium salts and to open a perspective way to the directed synthesis of substituted pyridines in high yields and selectivity. ${ }^{90}$

The studies in a field of the directed synthesis of bicyclic pyridine bases from 1ethynylcycloalkanes and carboxylic chloroanhydrides were the logical continuation of the reaction developed. The interaction of cyclic ethynylcarbinols with chloro-, bromo- and iodoanhydrides of carboxylic acids in the presence of two-component catalysts $\mathrm{ZnCl}_{2}-\mathrm{POCl}_{3}$ (1:1) under mild conditions $\left(20^{\circ} \mathrm{C}, 1 \mathrm{~h}\right)$ and a subsequent treatment of the mixture by $\mathrm{NH}_{4} \mathrm{OH}$ at $0{ }^{\circ} \mathrm{C}$ was found ${ }^{91}$ to give 2-alkyl-3,4-cycloalkenopyridines 72 . The synthesis of the latters by the other methods was found to be very difficult.

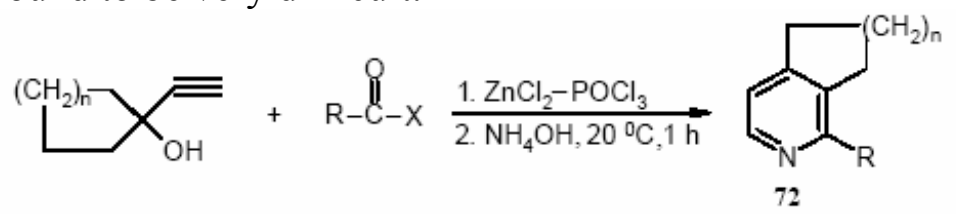

$$
\mathrm{X}=\mathrm{Cl}, \mathrm{Br}, \mathrm{I} ; \mathrm{R}=\mathrm{alkyl}
$$

The analysis of literature ${ }^{92,94}$ and own results allowed the authors ${ }^{91}$ to conclude that the formation of bicyclic pyridine molecules $\mathbf{7 2}$ from ethynylcarbinols and halogenated anhydrides of carboxylic acids proceeded via a step of a formation of pyrylium salts $\mathbf{7 3}$, then the latters were transformed to the target products in the treatment by $\mathrm{NH}_{4} \mathrm{OH}$ according to the following Scheme.

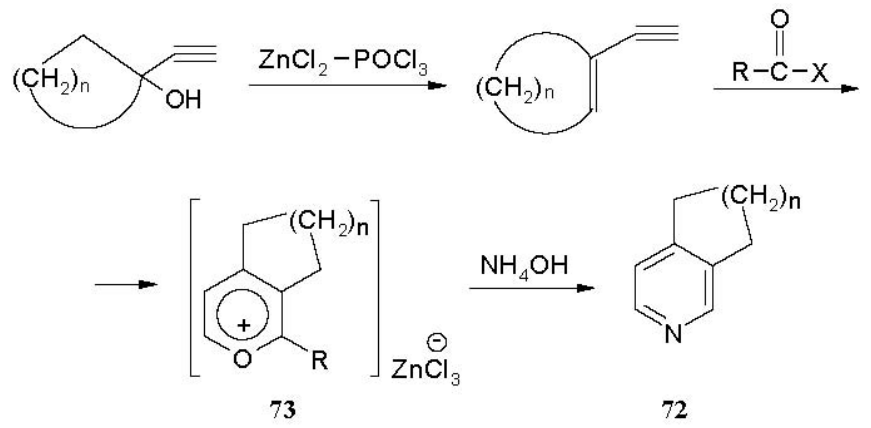


The method develped for a synthesis of bicyclic pyridines by a condensation of cyclic ethynylcarbinols with halogenated anhydrides of carboxylic acids in the presence of $\mathrm{ZnCl}_{2}-$ $\mathrm{POCl}_{3}$ opens the new, simple and efficient way to a synthesis of hardly accessed pyridine bases. $^{91-95}$

\section{Pyridine synthesis by liquid-phase condensation of aldehydes with $\mathrm{NH}_{3}$ under the effect of metal complex catalysts}

According to the reports ${ }^{95-97}$ a gas-phase condensation of benzaldehyde with acetic or butyric aldehydes and $\mathrm{NH}_{3}$ in the presence of heterogeneous catalysts on the basis of $\mathrm{Al}_{2} \mathrm{O}_{3}$ modified by transition metal complexes at $300-500{ }^{\circ} \mathrm{C}$ led to the formation of a mixture of 2- and 4phenylpyridines in total yield of no more than $30 \%$. The other substituted aromatic or aliphatic aldehydes including those containing functional substituents were not managed to be involved to the above reaction. On the other hand, alkylpyridines may be generated by a condensation of aliphatic aldehydes with $\mathrm{NH}_{3}$ in gas or liquid phase on heterogeneous catalysts. For example, 2methyl-5-ethylpyridine is produced from paraldehyde and $\mathrm{NH}_{3}$, and $\mathrm{MeCO}_{2} \mathrm{NH}_{4}{ }^{+}, \mathrm{CoCl}_{2}$, $\mathrm{NH}_{4} \mathrm{~F}$ or a mixture of $\mathrm{NH}_{4} \mathrm{~F}$ and $\mathrm{KF}$ are used as a catalyst. ${ }^{98,99}$ The method may be realized under strict conditions $\left(250-500{ }^{\circ} \mathrm{C}, 80-100 \mathrm{~atm}\right.$.) with low selectivity and in $60 \%$ yield. The reaction became complicated in the transition from formaldehyde and acetaldehyde to the highest aliphatic aldehydes. ${ }^{98}$

The synthesis of arylalkyl-substituted pyridines from alkyl(aryl)aldehydes under mild conditions was carried out in the presence of homogeneous Co-containing catalysts. Thus, a liquid-phase condensation of benzaldehyde with alkylaldehydes and urea in the presence of twocomponent catalyst $\mathrm{Co}$ (2-ethylhexanoate $)_{2}-\mathrm{AlR}_{3}$ at $200{ }^{\circ} \mathrm{C}$ for $4 \mathrm{~h}$ leads to a mixture of 2,3,5trisubstituted pyridines in total $80-95 \%$ yield. ${ }^{100}$ The authors accentuate the target products 74 and 75 may be produced in a joint condensation of benzaldehyde with alkylaldehydes. A formation of arylpyridines in condensation of benzaldehyde with urea under the set conditions is not observed.

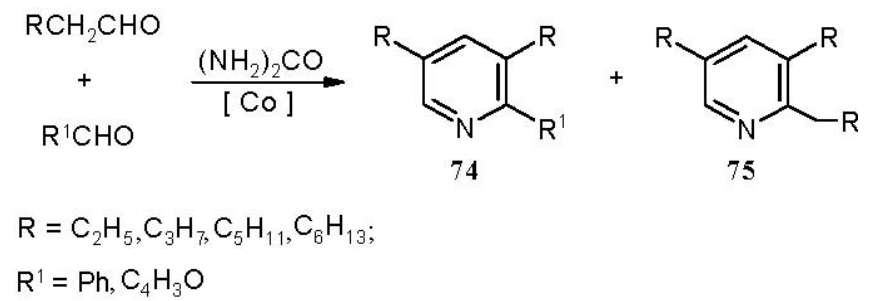

The catalytic system developed by authors ${ }^{100}$ allowed to fulfil the known gas-phase reaction of paraldehyde with benzaldehyde and ammonia under milder conditions in higher yields. ${ }^{101-}$ 103,104

In the reactions described above a role of urea concluded in a generation of $\mathrm{NH}_{3}$ under elevated temperature. $\left(\mathrm{NH}_{4}\right)_{2} \mathrm{SO}_{4}, \mathrm{NH}_{2} \mathrm{OH} \cdot \mathrm{HCl}, \mathrm{NH}_{4} \mathrm{Cl}, \mathrm{CH}_{3} \mathrm{NH}_{2}, \mathrm{NH}_{4} \mathrm{OH}$ may be used as sources of $\mathrm{NH}_{3}{ }^{105,106}$ Maximum yield of 75 was found to be achieved with the use of $\left(\mathrm{NH}_{4}\right)_{2} \mathrm{SO}_{4}$ 
or $\left(\mathrm{NH}_{2}\right)_{2} \mathrm{CO}$ and a catalyst $\mathrm{Co}$ (2-ethylhexanoate $)_{2}-\mathrm{AlEt}_{3}$ in $\mathrm{MeCN}, \mathrm{C}_{2} \mathrm{H}_{5} \mathrm{~N}, \mathrm{C}_{6} \mathrm{H}_{6}$ for 2 hours at $180-200{ }^{\circ} \mathrm{C}$ on the example of the reaction of paraldehyde with amines menthioned. Yield of 75 consists of $88-90 \%$, and a selectivity of a target product $98 \%$.
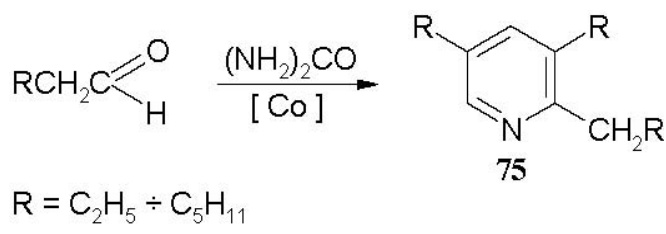

Under similar conditions a mixed condensation of benzaldehyde with butyric aldehyde and urea allows to give phenyl-3,5-diethylpyridine in $85 \%$ yield and with high selectivity.

The analogous approach was used in a generation of pyridines from acetalderhydes and $\left(\mathrm{NH}_{2}\right)_{2} \mathrm{HPO}_{4}$ (donor $\mathrm{NH}_{3}$ ) under the effect of catalytic amount of copper salts. ${ }^{107}$

The application of metal complex catalysts in the reactions described allowed to give alkyl(aryl)substituted pyridines under comparatively mild conditions in high yield and selectivity.

\section{Synthesis of cycloalkenyl- and alkatrienylpyridines by codimerization of vinylpyridines with 1,3-dienes catalyzed by $\mathrm{Zr}$ and Ni complexes}

At the beginning of 50 -s the first papers on a synthesis of cycloalkenylpyridines by thermal cyclocodimerization of vinylpyridines with 1,3-dienes were published. ${ }^{108-111}$ As a rule, the reactions mentioned proceed under strict conditions $\left(170^{\circ} \mathrm{C}\right)$ and in low yields $(25-30 \%)$. At the end of 80-s the highly effective methods for a synthesis of practically importance cycloalkenyland alkatrienylpyridines in high selectivity and yields were developed with the use of metal complex catalysts.

Thus, for example, the interaction of 2-vinylpyridine with butadiene in molar ratio of 2,5:6 respectively, in the presence of three-component catalytic system $\mathrm{Ni}(\mathrm{acac})_{2}-\mathrm{PPh}_{3}-\mathrm{AlEt}_{3}$ in benzene at no less than $110{ }^{\circ} \mathrm{C}$ for 6 hours gives 2-(deca-1E,4E,9-trienyl)pyridine 76 in no less than 55\%.yield. ${ }^{112,113}$

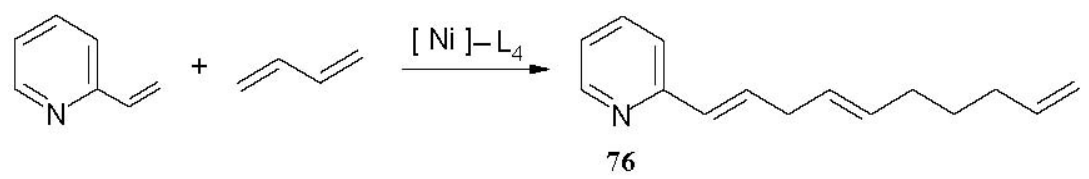

Under the optimum conditions 2-methyl-5-vinylpyridine, 4-vinylpyridine, and divinylpyridine react with butadiene to give decatrienylpyridines. In a case of divinylpyridines, for example, 2,3-divinylpyridine in the reaction with 1,3-butadiene, the authors ${ }^{14}$ observed together with linear cooligomers $\mathbf{7 7}$ a formation of mixed $\mathbf{7 8}$ and cyclocooligomers $\mathbf{7 9}$ in a ratio of ( 20):35:45 in total yield of 65\%. 


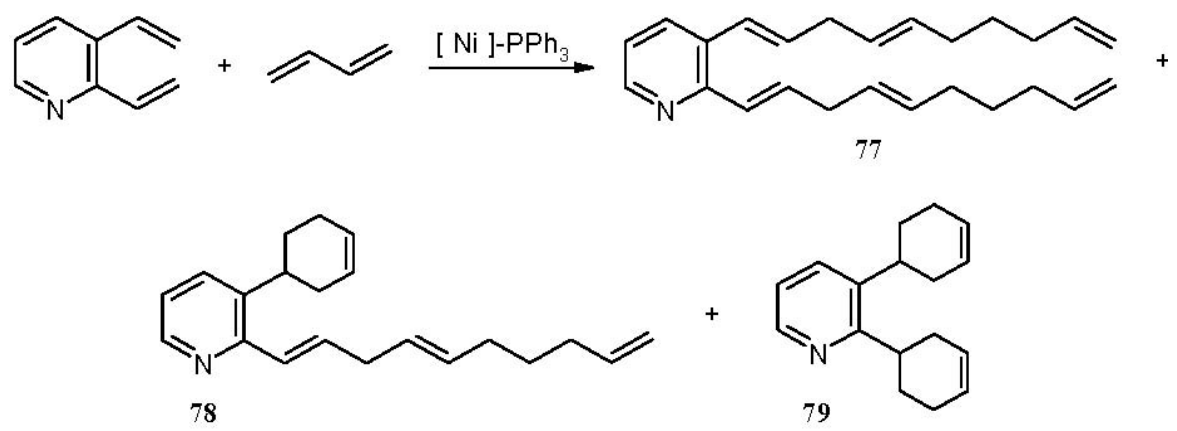

In contrast to butadiene, the other 1,3-dienes, for example, isoprene, 2-cyclopropyl-1,3butadiene, 2,3-dimethyl-1,3-butadiene, pyperilene, 2,3-dicyclopropylbutadiene react with vinylpyridines under the effect of phosphine complexes of nickel to give cycloalkenylpyridines $\mathbf{8 0}$ and $81 .{ }^{115}$

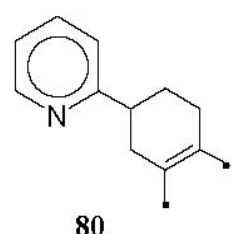

80
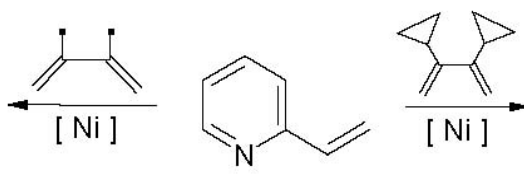

$\mathrm{Ni}]$

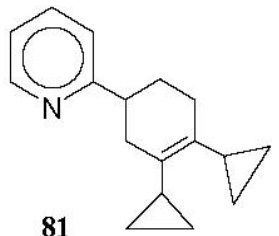

The authors ${ }^{115}$ propose the most probable mechanism for the interaction of 1,3-dienes with 2vinylpyridine in the presence of low-valence nickel complexes. In experiments with rather volume molecules of 1-, 2- or 2,3-disubstituted dienes (pyperilene, isoprene, 2cyclopropylbutadiene, 2,3-dimethylbutadiene, 2,3-dicyclopropylbutadiene) catalytic active $\mathrm{Ni}$ complexes are generated. The latters include by one molecule of 2-vinylpyridine and 1,3-diene to the coordination sphere of a central atom, that leads to [1:1]-cycloadducts. Complexes including two molecules of 1,3-diene and one molecule of 2-vinylpyridine are generated in a case of spatially less volume butadiene. A subsequent reduced elimination of a catalyst central atom from a catalytic matrix leads to a formation of the new $\mathrm{C}-\mathrm{C}$ bonds and to a generation of linear ${ }^{116}$ cooligomer $\mathbf{7 6}$ according to the following Scheme:

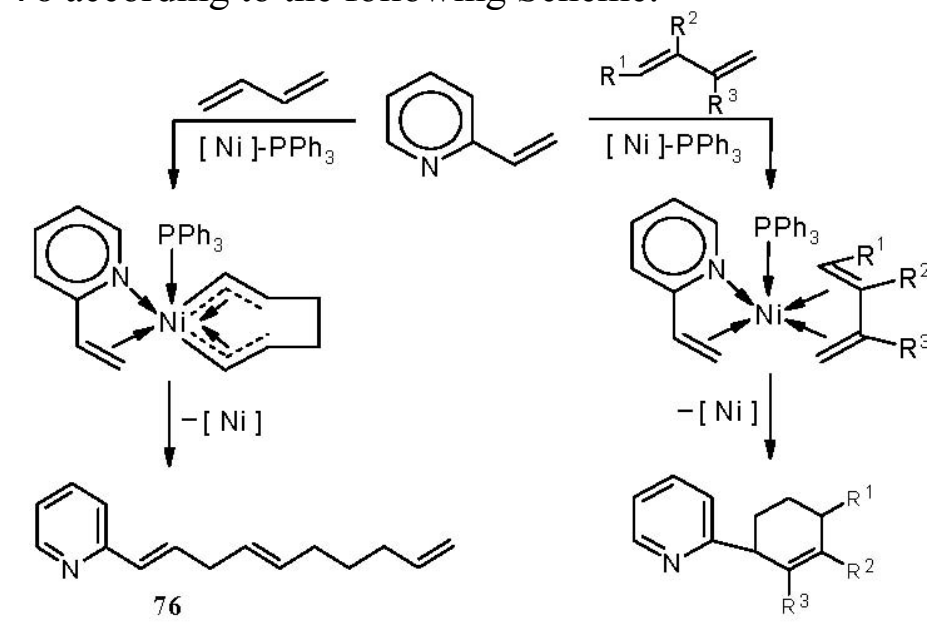


A cyclocodimerization of 2-vinylpyridine with cyclopentadiene was shown to be able to give selectively norbornenylpyridines in the presence of metal complex catalysts. ${ }^{117}$ From a number of catalysts tested on the basis of compounds $\mathrm{Ni}, \mathrm{Pd}, \mathrm{Fe}, \mathrm{Co}, \mathrm{Cu}, \mathrm{Rh}$, and $\mathrm{Zr}$ modified by phosphine ligands, reduced by organoaluminium and -magnesium reagents the three-component system of $\mathrm{Ni}$ (acac) $)_{2}-\mathrm{PPh}_{3}-\mathrm{AlEt}_{3}$ (1:3:4) or a catalyst $\mathrm{Cp}_{2} \mathrm{ZrCl}_{2}$ were found to have the highest activity on a reaction in benzene or toluene at $100-110^{\circ} \mathrm{C}$ for $4-6$ hours. ${ }^{118}$

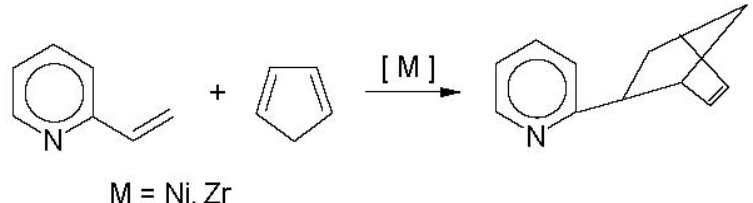

Substituted cyclopentadienes, such as, hexachlorocyclopentadiene and 1,1-dimethoxy2,3,4,5-tetrachlorocyclopenta-2,4-diene ${ }^{119,120}$ were involved to the reaction of cyclocodimerization with 2-vinylpyridine (2-methyl-5-vinylpyridine, 4-vinylpyridine) in the presence of highly active and selective catalysts on the basis of $\mathrm{Ni}$ and $\mathrm{Zr}$ complexes to give halogen-containing norbornenylpyridines 82 and 83 prospective for the subsequent functionalization and application in a synthesis of physiologically active preparations. ${ }^{121}$

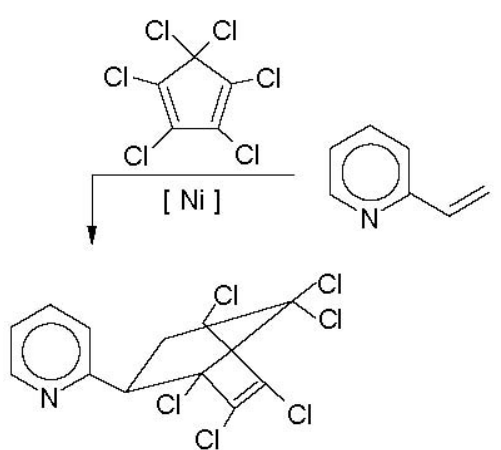

82
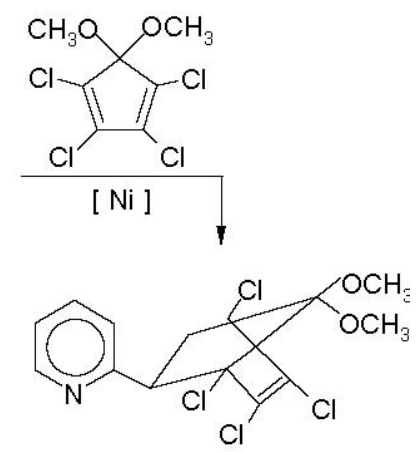

83

The examples described evidence that homogeneous metal complex catalysts significantly expand the frames of an application of the reaction of codimerization of vinylpyridines with 1,3dienes and allow to give the new unknown previously unsaturated derivatives of pyridine bases in high yields and selectivity.

\section{The other methods for a synthesis of pyridines in the presence of metal complex catalysts}

The methods for a generation of alkyl(aryl)substituted pyridines by cyclization of oxymes of $\beta, \gamma$ - and $\gamma, \delta$-unsaturated ketones in the presence of catalytic amount of palladium halogenides are 
little known and, hence, narrowly used in organic synthesis. ${ }^{122}$

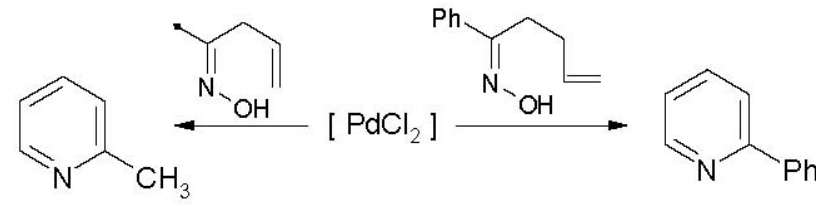

The interaction of 1,3-dienes with imines of pyridine series in the presence of nickelphosphine catalyst the a reaction of [3+2]-cycloaddition proceeds to give practically important nornicotine derivatives $\mathbf{8 4}$. $^{123}$ The authors pay attention to the generation of complexes with 2aza- $\pi$-allyl ligands under reaction conditions.

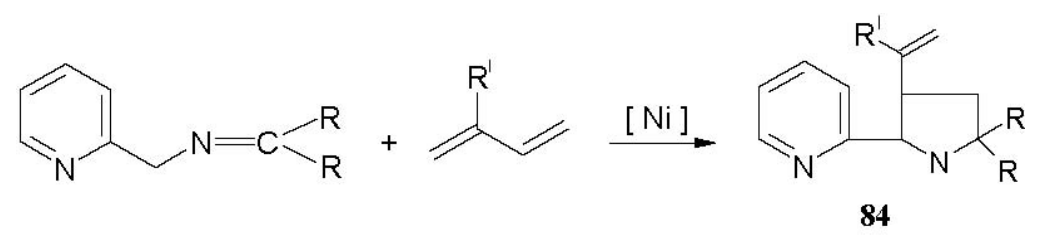

There are information on a possibility to obtain pyridine bases by the interaction of halogenated pyridines with allyl alcohols in the presence of $1 \mathrm{~mole} \% \mathrm{Pd}(\mathrm{OAc})_{2}{ }^{124}$ or with pyridylmagnesium halogenides under the effect of catalytic amount of copper salts. ${ }^{126}$ Yield of substituted pyridines consists of no more than $60 \%$ in both cases.

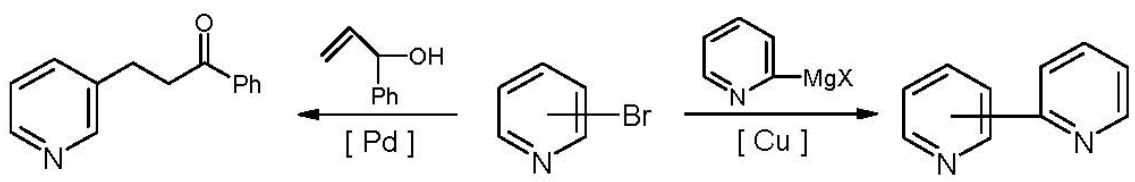

The paper $^{126}$ discusses a regiospecific synthesis of substituted pyridines from 2-azadienes and azomethines. The reactions were carried out in THF in the presence of catalytic amount of trifluoroacetic acid. The Diels-Alder products (pyrimidines or pyrazines) were predicted, however, substituted pyridines $\mathbf{8 5}$ were produced in $75-90 \%$ yields.

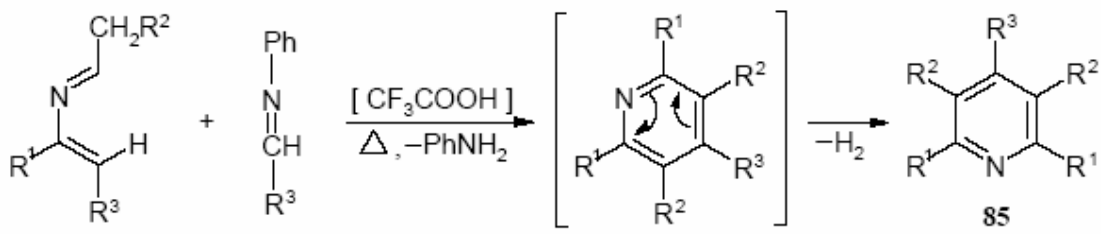

The examples listed in the review evidence the higher importance of metal complex catalysis in a synthesis of pyridine bases. At the same time, substituted pyridines are known to be the important semiproducts in thin organic synthesis and in the most cases to have biological activity, the latters are used as valuable initial compounds in a synthesis of drug preparations. 
For example, to the beginning of 90's from 1500 of the more effective and active drug preparations 73 were pyridine derivatives. Substituted pyridines are included to the vitamin composition ( $\left.\mathrm{B}_{3}, \mathrm{PP}, \mathrm{B}_{6}\right)$, tranquilizers, antidepressants, analeptic, sedative, analgeseous, antiinflammative, spasmalytic, vaso-dilating remedies and a series of other practically important preparations. ${ }^{126}$ Cyclocodimer of 4-vinylpyridine with butadiene is used as intermediate compound for a production of a series of cardiopreparations. ${ }^{127,128}$ Vinylpyridine cyclocodimers with 1,3-dienes are a part of compositions of odourants for cosmetic powders, liquid and solid detergents, perfumes, eau-de-Cologne, ${ }^{129}$ they are used to increase odour and smell of foods. ${ }^{130}$ There are information on the application of alkylpyridines for the extraction of noble metals, ${ }^{131}$ plant pest control, ${ }^{132}$ and as inhibitors of acidic steel corrosion. ${ }^{133}$

\section{Rare-earth element complexes in a synthesis of quinolines, phenanthridines and phenanthrolines}

To develop studies on a synthesis of pyridine bases initiating from aldehydes and simple amines the change of $\mathrm{Co}$ complexes for catalysts containing rare-earth element compounds $\left(\mathrm{PrCl}_{3}-\right.$ $\mathrm{PPh}_{3}-\mathrm{DMF}$ ) was shown by the authors of the review to carry out a liquid-phase condensation of aromatic amines with aldehydes to give the corresponding substituted quinolines, naphthyridines or phenanthrolines.

The condensation of substituted anilines with aliphatic aldehydes proceeds to give 2,3dialkylquinolines 86-101 in high yields (37-91\%) under optimum conditions (aniline:aldehyde = $1: 2,100{ }^{\circ} \mathrm{C}, 6 \mathrm{~h}$ ). The generation of $\mathrm{N}$-alkylanilines was observed together with that of target quinolines. The increase in alkyl radical sizes in initial aliphatic aldehydes does not effect on the yield of 86-101. ${ }^{134}$

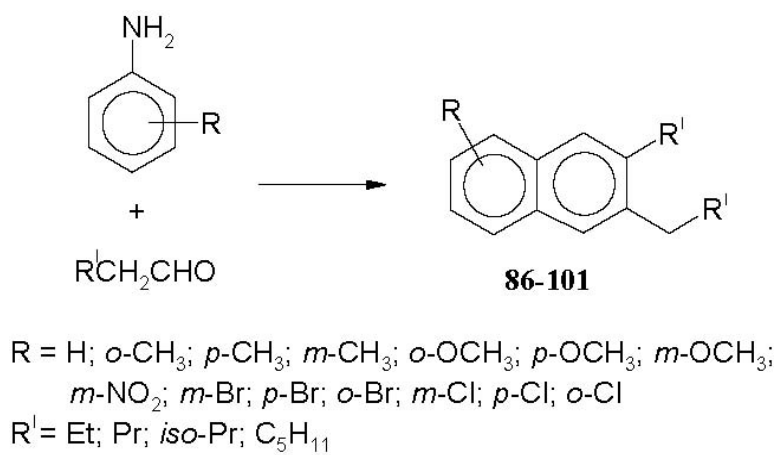

The nature and positions of substituents in a molecule of initial anilines were found to effect sufficiently on a reaction direction and quinoline yields 86-101.

Thus, o- and p-substituted anilines form 6- and 8-substituted quinolines, respectively. mSubstituted anilines give hardly-separated mixture of 5- and 7-substituted quinolines in low yields. The generation of 7-substituted quinolines in high yields was observed in application of $\left(\mathrm{Pr}^{+3}-\mathrm{PPh}_{3}-\mathrm{DMF}\right)$ as a catalyst in the reaction. ${ }^{135}$ 
The study on a mechanism of quinoline molecules formation on the example of the reaction of aniline and butyric aldehyde allowed to suppose that during the reaction the Knoevenagel condensation of initial aldehyde to $\alpha, \beta$-unsaturated aldehyde 102 proceeded initially, and then the latter reacted (according to Michael) with aniline to give aminoaldehyde 108. The latter is transformed to 4-oxytetrahydroquinoline $\mathbf{1 0 4}$ in the presence of praseodymium complexes. The dehydration and dehydrogenation lead to a generation of 2,3-disubstituted quinoline under reaction condition.
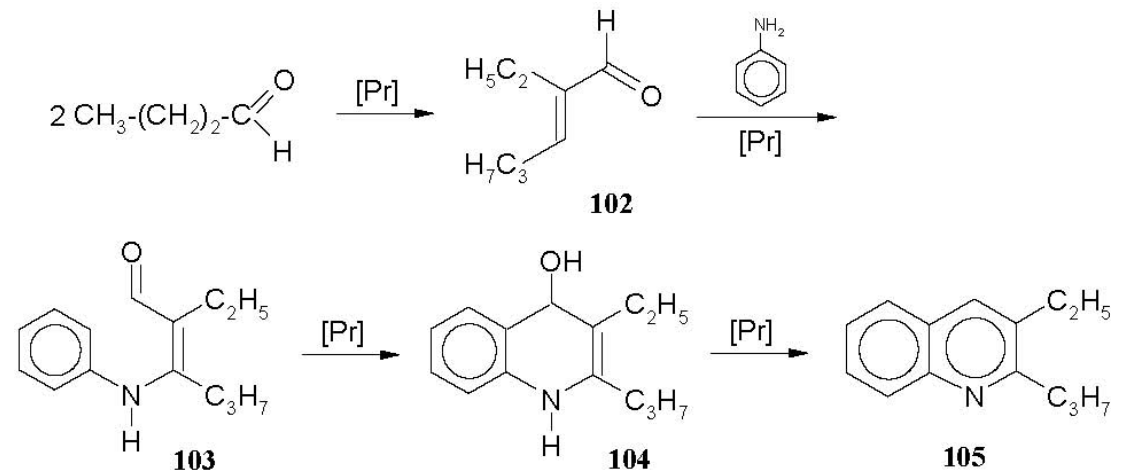

To extend a field of the reaction application and to produce aryl- and heteroaryl-substituted quinolines the authors ${ }^{135}$ studied a mixed liquid-phase condensation of aniline with butyric aldehyde, benzaldehyde or 4-pyridinealdehydes to give quinoline 106-109 under the effect of a catalyst $\mathrm{PrCl}_{3}-\mathrm{PPh}_{3}-\mathrm{DMF}$. ${ }^{135,136}$

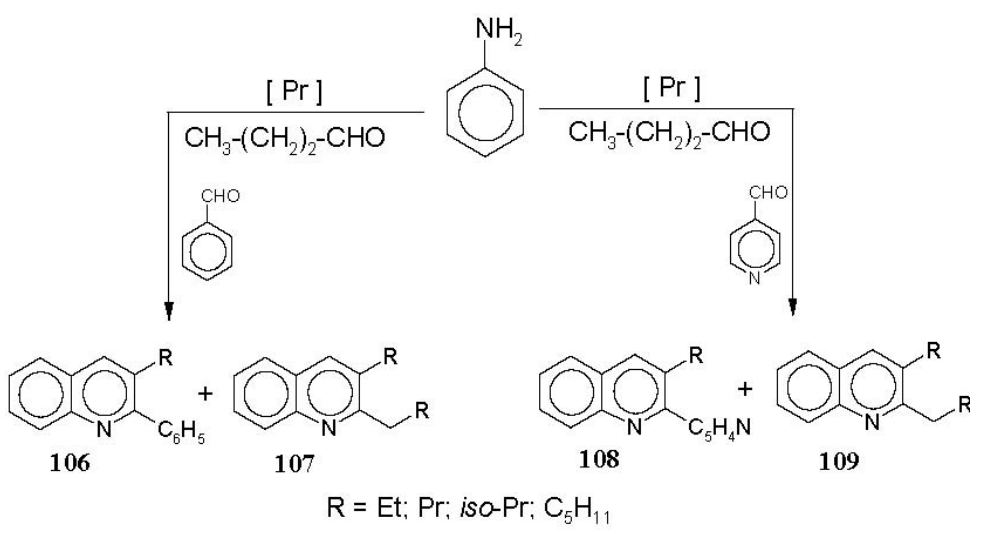

Under optimum conditions 3-aminoquinoline reacts with butyric aldehyde to give 2-propyl3-ethyl-5,6-benzo-1,7-naphthyridine 110, N-(2-ethylhexenyl-2)-3-aminoquinoline $\mathbf{1 1 1}$ and condensation products 112 and 113, initial aldehyde (content of no more than $8 \%$ ) in total $>95 \%$ yield. $^{137}$ 

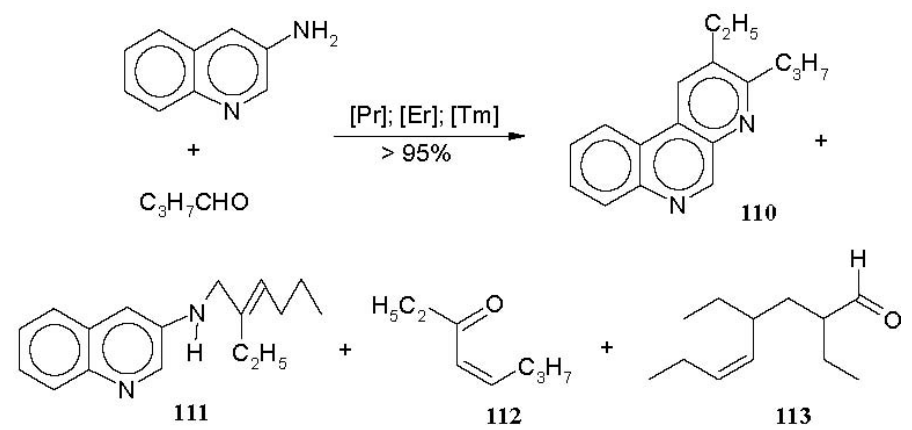

A mixed liquid-phase condensation of 3-aminoquinoline with butyric aldehyde and benzaldehyde $\left(1: 1: 1\right.$ ratio, $150{ }^{\circ} \mathrm{C}, 6 \mathrm{~h}, \mathrm{PrCl}_{3}-\mathrm{PPh}_{3}-\mathrm{DMF}$, toluene) was carried out to give 2phenyl-3-ethyl- and 3-ethyl-4-phenyl-5,6-benzo-1,7-naphtyridine 114 and the corresponding Narylsubstituted 3-aminoquinolines $\mathbf{1 1 5}$ and $\mathbf{1 1 6}$ in total 98\% yield. ${ }^{138}$

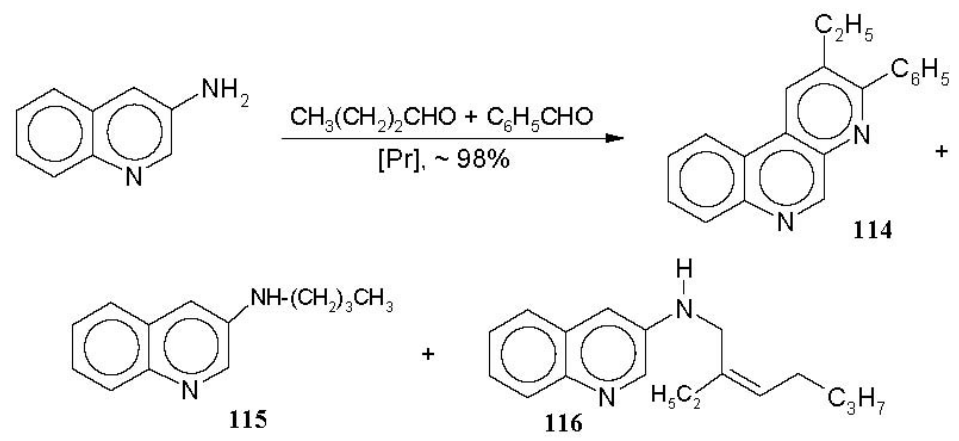

The change of benzaldehyde for 4-pyridinealdehyde allows to synthesize a mixture of 2ethyl-3-(4-pyridyl)benzo-1,7-naphthyridines 117 and 118 in 26 and 24\% yields respectively. ${ }^{139}$

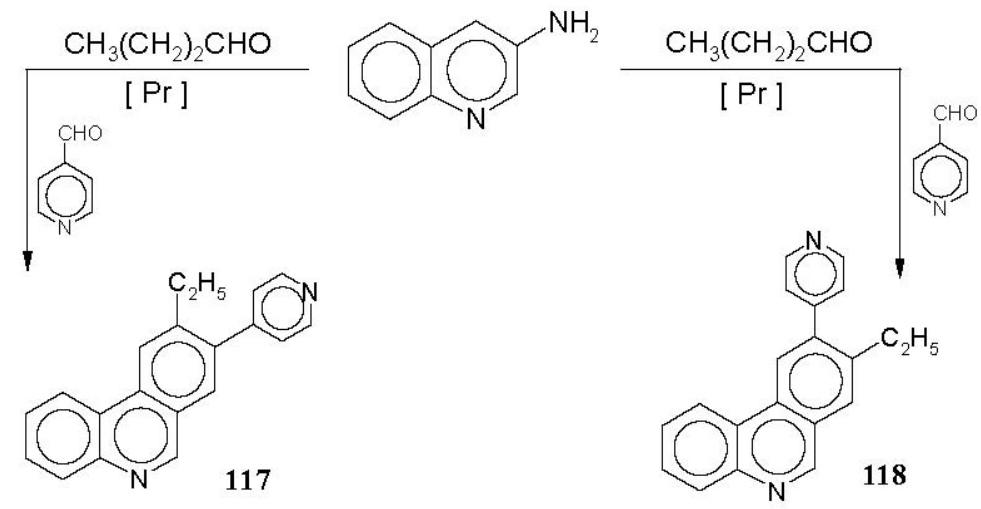

The interaction of 4-aminoquinoline with $\mathrm{C}_{4}-\mathrm{C}_{7}$ by aliphatic aldehydes gives substituted naphthyridines 119-122 under above conditions in 40\% yield, and in conversion of initial quinoline $55 \%$. The common amount of side products (alkylquinolines, dimers and trimers of butyric aldehyde) is no more than $10 \% .{ }^{139}$ 


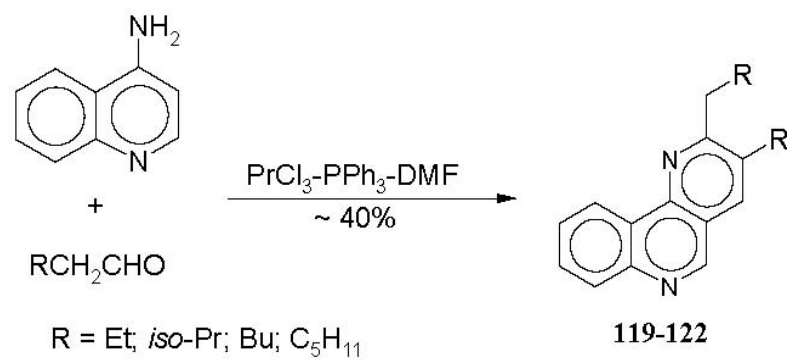

The condensation of 5-, 6- and 8-aminoquinolines with $\mathrm{C}_{4}-\mathrm{C}_{7}$ by aliphatic aldehydes, catalyzed by $\mathrm{Pr}, \mathrm{Tb}$ and $\mathrm{Sm}$ complexes $\left(150{ }^{\circ} \mathrm{C}, 6 \mathrm{~h}\right)$ leads to 1,7-, 4,7- and 1,10-substituted phenanthrolines, a position of amino group in a molecule of initial quinoline effects unsufficiently on the direction and yield of reaction products. In all experiments the yield of the corresponding 2,3-substituted phenanthrolines consists of 40-60\%, and in a conversion of initial monomers $95 \%$. $^{140}$

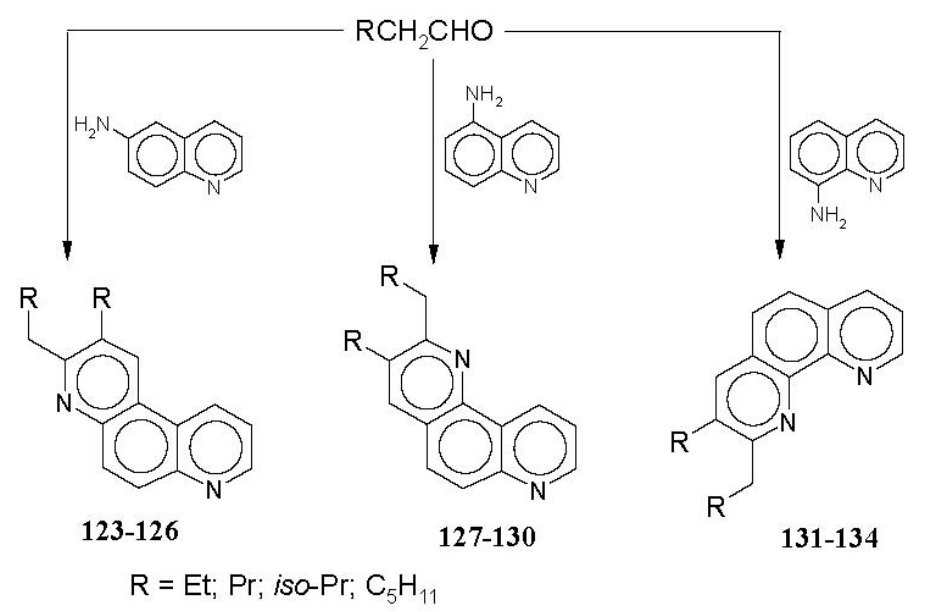

In a condensation of 5- and 8-aminoquinolines a position of amino group predetermines the only possible direction of cyclization to give the corresponding 1,7- and 1,10-phenanthrolines 123-130. In a case of 6-aminoquinolines, the only 4,7-phenanthrolines 131-134 were produced. A possibility to obtain a mixture of 2-phenyl-3-ethyl- 135 and 2-propyl-3-ethyl-1,10phenanthrolines 136 in 1:1 ratio in total yield of 45\% was shown on the example of a mixed condensation of 8-aminoquinoline with butyric aldehyde and benzaldehyde with the use of $\mathrm{PrCl}_{3}-\mathrm{PPh}_{3}-\mathrm{DMF}$ catalyst.
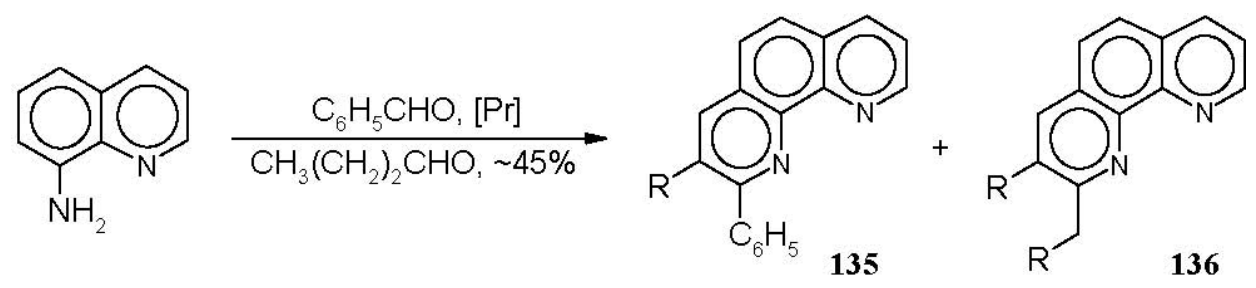

$\mathrm{R}=\mathrm{Et}$ 
According to analogous Scheme below substituted 1,7-, 1,10- and 4,7-phenanthrolines were synthesized by liquid-phase condensation of $\mathrm{o}, \mathrm{m}$ - and p-phenylenediamines with butyric aldehyde, that opens a simple and prospective method to synthesize hardly available previously substituted phenanthrolines, initiating from available aromatic diamines..$^{140,141}$

The reaction was studied on the example of a large number of $\mathrm{C}_{4}-\mathrm{C}_{6}$ aliphatic aldehydes, and high yields $(\sim 60 \%)$ of the corresponding phenanthrolines 137-148 were shown to be produced under the reaction conditions $\left(180^{\circ} \mathrm{C}, 8 \mathrm{~h}\right.$, catalyst $\left.\mathrm{PrCl}_{3}-\mathrm{PPh}_{3}-\mathrm{DMF}, 5 \mathrm{~mole} \%\right)$.

In contrast to the classic method of a synthesis of unsubstituted phenanthrolines according to the Skraup method based on a condensation of glycerine and acrolein with phenylenediamine in the presence of concentrated $\mathrm{H}_{2} \mathrm{SO}_{4}$ or $\mathrm{HNO}_{3}$. the authors ${ }^{142}$ have found, when the reaction proceeded in the presence of mixed catalyst $\mathrm{PrCl}_{3}-\mathrm{PdCl}_{2}-\mathrm{ZnCl}_{2}-\mathrm{PPh}_{3}-\mathrm{DMF}$ in a ratio of 1:1:2:1:1 at $100-120^{\circ} \mathrm{C}$, the yields of 1,7-, 1,10- and 4,7-phenanthrolines 149-151 rised from $50 \%$ to $90 \%$.
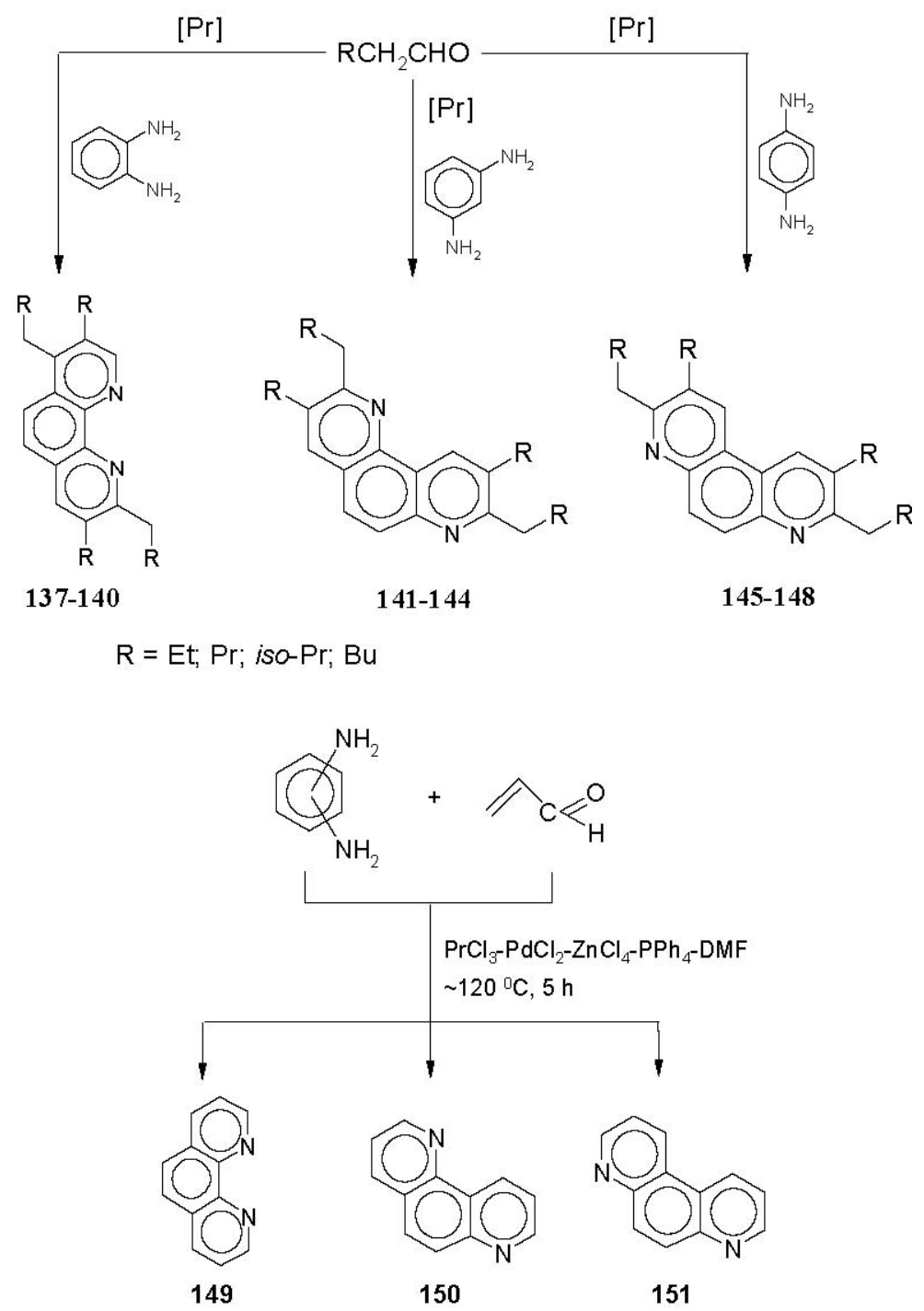


\section{References}

1. Shrauzer, G. N. Chem. Ber. 1961, 94, 1403.

2. Funk, R. L.; Vollhardt, K. P. C. J. Am. Chem. Soc. 1977, 99, 5483.

3. Aalbersberg, W. G. L.; Barkovich, A. J.; Funk, R. L. et al. J. Am. Chem. Soc. 1975, 97, 5600.

4. Iwashita, Y.; Tamura, F. Bull. Chem. Soc. Jpn. 1970, 43, 1517.

5. Otsuka, S.; Nakamura, A.; Yamagata, T.; Tani K. J. Am. Chem. Soc. 1972, 94, 1037.

6. Wilke G. Pure Appl. Chem. 1978, 50, 677.

7. Moseley, K.; Maitlis, P. M. J. Chem. Soc., Chem. Commun. 1971, 1604.

8. Ito, Ts.; Hasegawa, S.; Takahashi, Y.; Ishii, Y. J. Organometal. Chem. 1974, 73, 401.

9. Yamazaki, H.; Wakatsuki, Y. J. Organometal. Chem. 1977, 139, 157.

10. Yamazaki, H.; Hagihara, N. J. Organometal. Chem. 1967, 7, P22.

11. Wakatsuki, Y.; Kuramitsu, T.; Yamazaki, H. Tetrahedron Lett. 1974, 4549.

12. Wakatsuki,Y.; Yamazaki, H. J. Chem. Soc., Chem. Commun. 1973, 280.

13. Hillard, R. L.; Vollhardt, K. P. J. Am. Chem. Soc. 1977, 99, 4058.

14. Wakatsuki, Y.; Yamazaki, H. Tetrahedron Lett. 1973, 3383.

15. Vollhardt, K. P. C.; Bergman, R. G. J. Am. Chem. Soc. 1974, 96, 4996.

16. Bönnemann, H.; Brinkman, R.; Schenkluhn, H. Synthesis. 1974, 575.

17. Clement, R. A. U.S. 3829429 (1974); Ref. Zh. Khim. 1975, 11, H232П; Chem. Abstr. 1974, 81, 135962h.

18. Levin, D. Z.; Demidova, N. K.; Mortikov, E. S. i dr. Tezisy dokladov Vsesoyuznogo soveshchaniya po khimii i tekhnologii piridinovykh osnovanii dlya proizvodstva khimicheskikh sredstv zashity rastenii. Moskva (VDNKh), 1983, S. 15.

19. Levin, D. Z.; Mortikov, E. S.; Demidova, N. K. et al. Soviet Union Pat. 1105491 (1984). From Otkrytia, Izobret. 1984, (28), 69; Chem. Abstr. 1984, 101, 171116a.

20. O'Murchu, C. Swiss Pat. 645621 (1984); Ref. Zh. Khim. 1985, 10, H234П; Chem. Abstr. 1985, 102, 78738r.

21. Abronin, I. A.; Gorb, L. G., Levin, D. Z.; Demidova, N. K.; Mortikov, E. S. Izv. AN SSSR., Ser. khim. 1982, 2623.

22. Yamazaki, H.; Hagihara, N. J. Organometal. Chem. 1970, 21, 431.

23. Yasufuku, K.; Yamazaki, H. J. Organometal. Chem. 1977, 127, 197.

24. McAlister, D. R.; Bercaw, J. E.; Bergman, R. G. J. Am. Chem. Soc. 1977, 99, 1666.

25. Wakatsuki, Y.; Yamazaki, H. J. Organometal. Chem. 1977, 139, 169.

26. Wakatsuki, Y.; Nomura, O.; Yamazaki, H.; Kitaura, K.; Morokuma, K. J. Am. Chem. Soc. 1983, 105, 1907.

27. Yamazaki, H.; Wakatsuki, Y. J. Organometal. Chem. 1984, 272, 251.

28. Wakatsuki, Y.; Yamazaki, H. J. Chem. Soc., Dalton Trans. 1978, 1278.

29. Bönnemann, H.; Brinkmann, R. Synthesis. 1975, 600.

30. Boennemann, H.; Schenkluhn, H. Soviet Union Pat. 558642 (1977). [Ger. Offen. 2 
416295] From Otkrytia, Izobret., Prom. Obraztsy, Tovar. Znaki 1977, (18), 162; Ref. Zh. Khim. 1976, 18, H202П; Chem. Abstr. 1976, 84, 30909e.

31. Boennemann, H.; Samson, M. Soviet Union Pat. 888817 (1981). [Ger. 2840460 (1980)] From Otkrytia, Izobret., Prom. Obraztsy, Tovar. Znaki 1981, (45), 280; Chem. Abstr. 1980, 93, 95136f.

32. Wakatsuki, Y.; Yamazaki, H. Japan Kokai 7725780 (1977); Chem. Abstr. 1977, 87, $68168 \mathrm{u}$.

33. Taarit, Y.; Diab, Y.; Elleuch, B.; Kerkani, M.; Chihaoul, M. J. Chem. Soc., Chem. Commun. 1986, 402.

34. Bönnemann, H. Angew. Chem. 1978, 90, 517.

35. Chiusoli, G. R.; Pallini, L.; Terenghi, M. G. Trans. Met. Chem. 1984, 9, 360.

36. Vollhardt, K. P. C. Angew. Chem. 1984, 96, 525.

37. Bönnemann, H. Angew. Chem. 1985, 97, 264.

38. Bönnemann, H.; Brijoux, W. In Aspects of Homogeneous catalysis. The Cobalt Catalyzed Synthesis of Pyridines and its Derivatives / Ed. R. Ugo; Dordrecht: Reidel D., 1984, 5, pp. 75-196.

39. Wakatsuki, Y.; Yamazaki, H. Synthesis. 1976, 26.

40. Bönnemann, H.; Brijoux, W. Bull. Soc. Chim. Belg. 1985, 94, 635.

41. Diversi, P.; Ingrosso, G.; Lucherini, A.; Vanacore, D. J. Mol. Catal. 1987, 41, 261.

42. Kayushina, E. H.; Levin, D. Z.; Mortikov, E.S.; Promonenkov, V. K. Izv. AN SSSR., Ser. Khim. 1986, 1625.

43. Kayushina, E. H.; Mortikov, E. S.; Promonenkov, V. K. Levin, D. Z. Tezisy dokladov Vsesoyuznogo soveshchaniya "Khimiya i tekhnologiya geterotsiklov (nitrily, izotsianaty i dr.) dlya proizvodstva khimitcheskikh sredstv zashchity rastenii. Moskva (VDNKh), 1985, S. 69.

44. Naiman, A.; Vollhardt, K. P. C. Angew. Chem. 1977, 89, 758.

45. Vierhapper, F. W.; Eliel, E. L. J. Org. Chem. 1975, 40, 2729.

46. Brien, D. J.; Naiman, A.; Vollhardt, K. J. Chem. Soc., Chem. Commun. 1982, 133.

47. Hardt, P. Swiss Pat. 612939 (1979) [Ger. Offen 2615309 (1977)]; Ref. Zh. Khim. 1980, 11, H173П; Chem. Abstr. 1977, 87, 23068p.

48. Hardt, P.Ger. Offen. 2742541 (1978); Chem. Abstr. 1978, 89, 24163 u.

49. Hardt, P. Swiss Pat. 622008 (related) [DE 2615309 (1977)] (1981); Ref. Zh. Khim._1981, 20, Н160П; Chem. Abstr. 1977, 87, 23068p.

50. Tatone, D.; Dich, T. C.; Nacco, R.; Botteghi, C. J. Org. Chem. 1975, 40, 2987.

51. Azzena, U.; Chelluci, G.; Delogu, G.; Botteghi, C. Gazz. Chim. Ital. 1986, 116, 307.

52. Bönnemann, H.; Natarajan, G. Erdöl und Kohle Erdgas - Petrochem. 1980, 33, 328; Ref. Zh. Khim. 1981, 7, Ж176.

53. Abramovitch, R. A. In Heterocyclic compounds. Bd.14: Pyridine and its derivatives. Wiley, 1975, Teil 4, Kap. 15, p. 189f.

54. Cioni, P.; Diversi, P.; Ingrosso, G.; Lucherini, A.; Ronca, P. J. Mol. Catal. 1987, 40, 337. 
55. Diversi, P.; Ingrosso, G.; Lucherini, A.; Minutillo, A. J. Mol. Catal. 1987, 40, 359.

56. Boennemann, H.; Bogdanovic, B. Ger. Offen. 3 205550, 1983; Ref. Zh. Khim. 1984, 24, H188П; Chem. Abstr. 1984, 100, 22805 b.

57. Bönnemann, H.; Bogdanovic, B.; Brijoux, W. et al. Catalysis of organic reactions (Chemical industries: Vol.18); Marsel Dekker, 1984; pp. 31-62.

58. Hardt, P. Swiss Pat. 646438, 1984; Ref. Zh. Khim. 1985, 13, H231П; Chem. Abstr. 1985, 102, 204109b.

59. Boennemann, H. Ger. Offen. 3 117363, 1982; Ref. Zh. Khim. 1984, 4, H213П; Chem. Abstr. 1983, 98, 89186j.

60. Bönnemann, H.; Brijoux, W.; Brinkmann, R.; Meurers, W. Helv. chim. acta 1984, 67, 1616.

61. Bönnemann, H.; Bogdanovic, B.; Brinkmann, R. et al. Angew. Chem. 1983, 95, 749.

62. Wakatsuki, Y.; Yamazaki, H. Bull. Chem. Soc. Jpn. 1985, 58, 2715.

63. Vitulli, G.; Bertozzi, S.; Lazzaroni, R.; Salvadori, P. J. Organometal. Chem. 1986, 307, C35.

64. Vitulli, G.; Bertozzi, S.; Vignali, M.; Lazzaroni, R.; Salvadori, P. $5^{\text {th }}$ International Symposium on Homogeneous Catalysis (Programme \& Abstracts). Kobe, 1986, p. 69.

65. Vitulli, G.; Bertozzi, S.; Vignali, M.; Lazzaroni, R.; Salvadori, P. J. Organometal. Chem. 1987, 326, C33.

66. Vollhardt, K. P. C.; Naiman, A. U.S. Pat. Appl. 886119 (1978); Chem. Abstr. 1979, 90, $186806 \mathrm{~d}$.

67. Vollhardt, K. P. C.; Naiman, A. U.S. Pat. Appl. 54926 (1982) [U.S.4 328343, 1982]; Ref. Zh. Khim. 1983, 11, H183П; Chem. Abstr. 1980, 93, 95139j.

68. Chiusoli, G. P.; Pallini, L.; Terenghi, G. Trans. Met. Chem. 1983, 8, 250.

69. Chiusoli, G. P.; Pallini, L.; Terenghi, G. Eur. Pat. Appl. EP 92288, 1983; Chem. Abstr. 1984, 100, 121035g.

70. Hillard, R. L.; Parnell, C. A.; Vollhardt, K. P. C. Tetrahedron 1983, 39, 905.

71. Parnell, C. A.; Vollhardt, K. P. C. Tetrahedron 1985, 41, 5791.

72. Geiger, R. E.; Lalonde, M.; Stoller, H.; Schleich, K. Helv. chim. acta 1984, 67, 1274.

73. Selimov, F. A.; Khafizov, V. R.; Dzhemilev, U. M. Izv. AN SSSR, Ser.Khim. 1983, 1885.

74. Dzhemilev, U. M.; Selimov, F. A.; Khafizov, V. R. Izv. AN SSSR, Ser.Khim. 1986, 1628.

75. Selimov, F. A.; Khafizov, V. R.; Dzhemilev, U. M. Izv. AN SSSR, Ser.Khim. 1985, 1847.

76. Selimov, F. A.; Khafizov, V. R.; Dzhemilev, U. M. Khim. Geterotsykl. Soedin. 1984, 360.

77. Erre, C.; Pedra, A.; Arnaud, M.; Roussel, Ch. Tetrahedron Lett. 1984, 25, 515.

78. Rutman, O. G.; Selimov, F. A. Tezisy dokladov X konferentsii molodykh uchenykh. Ufa, 1985, S. 9.

79. Selimov, F. A.; Dzhemilev, U. M.; Tolstikov, G. A.; Rutman, O. G.; Ptashko, O. A. Soviet Union Pat. 1 213027, 1986; From Otkrytiya, Izobret. 1986, (7), 140; Chem. Abstr. 1986, 105, 172300a.

80. Selimov, F. A.; Rutman, O. G.; Dzhemilev, U. M. Izv. AN SSSR, Ser.Khim. 1986, 688. 
81. Selimov, F. A.; Dzhemilev, U. M.; Rutman, O. G.; Akhmetov, A. Zh. Tezisy dokladov Vsesoyuznoi konferentsii «Khimiya nepredel'nykh soedinenii». Kazan, 1986, 1, S. 130.

82. Dzhemilev, U. M.; Selimov, F. A.; Khafizov, V. R.; Rutman, O. G.; Akhmetov, A. Zh.; Tolstikov, G. A. VI International Conference on Organic Synthesis. (Programme and Abstracts of Papers). Moscow, 1986, p. 206.

83. Selimov, F. A.; Rutman, O. G.; Dzhemilev, U. M. Soviet Union Pat. 1373705 (1988); From Otkrytiya, Izobret. 1988, (6), 83; Chem. Abstr. 1989, 110, 8052d.

84. Stetter, H.; Reischl, A. Chem. Ber. 1960, 93, 1253.

85. Siemiatycki, M.; Fugnitto, M. Bull. Chem. Soc. Fr. 1961, 538.

86. Bos, H. J.; Arens, J. F. Rec. trav. chim. 1963, 82, 845.

87. Dzhemilev, U. M.; Selimov, F. A.; Rutman, O. G. Izv. AN SSSR, Ser.Khim. 1988, 2600.

88. Selimov, F. A.; Rutman, O. G.; Dzhemilev, U. M. Soviet Union Pat. 1384577 (1988); From Otkrytiya, Izobret. 1988, (12), 78; Chem. Abstr. 1988, 109, 170240q.

89. Selimov, F. A.; Rutman, O. G.; Dzhemilev, U. M. Soviet Union Pat. 1384581 (1988); From Otkrytiya, Izobret. 1988, (12), 78; Chem. Abstr. 1989, 110, 173090x.

90. Rutman, O. G. Diss. kand. khim. nauk. Ufa, Institut Organicheskoi Khimii UNTs RAN, 1990.

91. Selimov, F. A.; Rutman, O. G.; Dzhemilev, U. M. Izv. AN SSSR, Ser.Khim. 1988, 2604.

92. Balaban, A.; Dinculescu, A. et al. In Advances in Heterocyclic Chemistry. Suppl. 2 to Vol. 10. Pyrylium Salts: Synthesis, Reactions, and Physical Properties / Ed. by A. R. Katritzky; New York-London-Toronto:Academic Press, 1982, 434 pp.

93. Dorofeenko, G. N.; Sadekova, E. I.; Kuznetsov, E. V. Preparativnaya khimiya pirilievykh solei; Rostov: Izdatel'stvo Rostovskogo Universiteta, 1972, $234 \mathrm{s.}$

94. Dorofeenko, G. N.; Zhdanov, Yu. A.; Etmetchenko, L. N. Khim. Geterotsykl. Soedin. 1969, 781.

95. Chichibabin, A. E.; Orochko, D. I. Zh. Russ. Khim. Obshch. 1930, 62, 1201.

96. Chichibabin, A. E. Uspekhi khim. 1936, 5, 481.

97. Prostakov, N. S.; Soldatenkov, A. T.; Fedorov, V. O.; Polosin, V. M. Soviet Union Pat. 761463 (1980); From Otkrytiya, Izobret. 1980, (33), 119; Chem. Abstr. 1981, 94, 103179k.

98. Farberov, M. I.; Antonova, V. V.; Ustavshikov, B. F.; Titova, N. A. Khim. Geterotsyk1. Soedin. 1975, 1587.

99. Chumakov, Yu. I. Piridinovye osnovaniya; Kiev: Tekhnika, 1965, 192 s.

100. Dzhemilev, U. M.; Selimov, F. A.; Akhmetov, A. Zh.; Fatykhov, A. A. Izv. AN SSSR, Ser.Khim. 1988, 2335.

101. Dzhemilev, U. M.; Selimov, F. A.; Akhmetov, A. Zh. Soviet Union Pat. 1395629 (1988);

From Otkrytiya, Izobret. 1988, (18), 98; Chem. Abstr. 1988, 109, 230814s.

102. Dzhemilev, U. M.; Selimov, F. A.; Akhmetov, A. Zh. Soviet Union Pat. 1318593 (1987);

From Otkrytiya, Izobret. 1987, (23), 87; Chem. Abstr. 1987, 107, 217499g.

103. Dzhemilev, U. M.; Selimov, F. A.; Akhmetov, A. Zh. Soviet Union Pat.1 416487 (1988);

From Otkrytiya, Izobret. 1988, (30), 88; Chem. Abstr. 1989, 110, 212628 a. 
104. Dzhemilev, U. M.; Selimov, F. A.; Akhmetov, A. Zh. Soviet Union Pat. 1397438 (1988);

From Otkrytiya, Izobret. 1988, (19), 97; Chem. Abstr. 1988, 109, 172558y.

105. Selimov, F. A.; Akhmetov, A. Zh.; Dzhemilev, U. M. Izv. AN SSSR, Ser.Khim. 1987, 2042.

106. Dzhemilev, U. M.; Selimov, F. A.; Akhmetov, A. Zh. Soviet Union Pat.1 286594 (1987);

From Otkrytiya, Izobret. 1987, (4), 95; Chem. Abstr. 1987, 106, 213772x.

107. Kusunoki, Y.; Okazaki, H.; Sano, E. Ger. Offen. 2155896 (1973) [Brit. 1 369032(1973)]; Chem. Abstr. 1973, 79, 31895 f.

108. Doering, W. E.; Rhoads, S. J. J. Am. Chem. Soc. 1953, 75, 4738.

109. Petrov, A. A.; Lyudvig, V. Zh. Obshch. Khim. 1955, 25, 739.

110. Petrov, A. A.; Lyudvig, V. Zh. Obshch. Khim. 1956, 26, 51.

111. Meek, J. S.; Merrow, R. T.; Ramey, D. E.; Cristol, S. J. J. Am. Chem. Soc. 1951, 73, 5563.

112. Selimov, F. A.; Ptashko, O. A.; Khafizov, V. R. Tezisy dokladov Vsesoyuznoi konferentsii «Primenenie metallokompleksnogo kataliza v organicheskom sinteze». Ufa, 1989, S. 13.

113. Ptashko, O. A.; Khafizov, V. R. Tezisy dokladov Vsesoyuznoi konferentsii molodykh uchenykh. Ufa, 1989, S. 15.

114. Dzhemilev, U. M.; Ptashko, O. A.; Tolstikov, G. A. Tezisy dokladov Vsesoyuznoi konferentsii «Sozdanie perspektivnykh pestitsidov i syr'ya dlya ikh proizvodstva». Ufa, 1989, S. 21.

115. Selimov, F. A.; Ptashko, O. A.; Fatykhov, A. A.; Khalikova, N. R.; Dzhemilev, U. M. Izv. AN SSSR, Ser.Khim. 1993, 916.

116. Dzhemilev, U. M.; Selimov, F. A.; Ptashko, O. A. Soviet Union Pat. 1786026 (1992);

From Izobret. 1992, (19).

117. Dzhemilev, U. M.; Selimov, F. A.; Ptashko, O. A. Soviet Union Pat. 1735286 (1992);

From Izobret. 1992, (19).

118. Dzhemilev, U. M.; Selimov, F.A.; Ptashko, O.A. IX International Symposium on Homogeneous Catalysis (Programme and Abstracts of Papers). Ierusalem, 1994, p. 32.

119. Selimov, F.A.; Khusnutdinov, R. A.; Ptashko, O. A.; Dzhemilev, U. M. Tezisy dokladov I c'ezda khimikov, neftekhimikov, neftepererabotchikov i rabotnikov promyshlennosti stroimaterialov Respubliki Bashkortostan «Neftedobycha, neftekhimiya i kataliz». Ufa, 1992, S. 104.

120. Ptashko, O. A. Diss. ... kand. khim. nauk. Ufa, Institut neftekhimii i kataliza AN RB i UNTs RAN, 1999.

121. Selimov, F.A.; Krut'kov, V. M.; Vakhitov, V. A.; Yakhin, I. Ya.; Balakhontsev, E. N.; Kashin, A. A.; Khusnutdinov, R. A.; Ptashko, O. A.; Dzhemilev, U. M. Tezisy dokladov I c'ezda khimikov, neftekhimikov, neftepererabotchikov i rabotnikov promyshlennosti stroimaterialov Respubliki Bashkortostan «Neftedobycha, neftekhimiya i kataliz». Ufa, 1992, S. 95. 
122. Hosokawa, T.; Shimo, N.; Maeda, K.; Sonoda, A.; Murahashi, Shun-Ichi. Tetrahedron Lett. 1976, 383.

123. Heinz, P.; Reinehr, D. Helv. chim. acta 1978, 61, 1115.

124. Tamaru, Y.; Yamada, Y.; Yoshida Zen.-Ichi. J. Org. Chem. 1978, 43, 3396.

125. Lang, G. H. Ger. Offen. 2521969 (1975); Chem. Abstr. 1976, 84, 105407a.

126. Lukevits, E. Khim. Geterotsykl. Soedin. 1995, 723.

127. Kaiho, T. Jpn. Kokai Tokkyo Koho JP 62.126171 [87.126171] (1987); Chem. Abstr. 1988, 108, 131585r.

128. Kaiho, T. Jpn. Kokai Tokkyo Koho JP 62.126170 [87.126170] (1987); Chem. Abstr. 1988, 108, $21727 f$.

129. Boden, R. U.S. US 4720481 (1988); Chem. Abstr. 1988, 108, $210006 f$.

130. Boden, R.; Grim, C. U.S. US 4539143 (1985); Chem. Abstr. 1986, 104, 148749n.

131. Selimov, F.A.; Dzhemilev, U. M.; Khafizov, V. R.; Konyk, O. A.; Rutman, O. G. Tezisy dokladov I Vsesouyznoi konferentsii «Khimiya i primenenie nevodnykh rastvorov». Ivanovo, 1986, 3, S. 459.

132. Dzhemilev, U. M.; Selimov, F.A.; Khafizov, V. R.; Ptashko, O. A.; Khusnutdinov, R. A.; Tolstikov, G. A. XIV Mendeleevskii s'ezd po obshchei i prikladnoi khimii. Referaty dokladov i soobshchenii. Tashkent, 1989, 1, S. 252.

133. Selimov, F.A.; Khusnutdinov, R. A.; Ptashko, O. A. i dr. Tezisy dokladov. Mezhvuzovskii sbornik nauchnykh trudov UGNTU «Neft i gas-97». Ufa, 1997, S. 61.

134. Dzhemilev, U. M.; Selimov, F.A.; Khusnutdinov, R. A. Izv. AN SSSR, Ser.Khim. 1990, 2447.

135. Dzhemilev, U. M.; Selimov, F.A.; Khusnutdinov, R. A.; Fatykhov, A. A.; Khalilov, L. M.; Tolstikov, G. A. Izv. AN SSSR, Ser.Khim. 1991, 1407.

136. Dzhemilev, U. M.; Selimov, F.A.; Khusnutdinov, R. A. Soviet Union Pat. 1735287 (1992); From Izobret. 1992, (19).

137. Dzhemilev, U. M.; Selimov, F.A.; Khusnutdinov, R. A. i dr. Izv. AN SSSR, Ser.Khim. $1992,1139$.

138. Dzhemilev, U. M.; Selimov, F.A.; Khusnutdinov, R. A. Soviet Union Pat. 1766918 (1992); From Izobret. 1992, (37).

139. Selimov, F.A. Diss. dokt. khim. nauk. Ufa, Institut neftekhimii i kataliza AN RB i UNTs RAN, 1998.

140. Dzhemilev, U. M.; Selimov, F.A.; Khusnutdinov, R. A. Soviet Union Pat. 2119916 (1998); From Izobret. 1998, (28).

141. Dzhemilev, U. M.; Selimov, F.A.; Khusnutdinov, R. A., Ptashko, O. A. Soviet Union Pat.2 117006 (1998); From Izobret. 1998, (22).

142. Khusnutdinov, R. A. Diss. kand. khim. nauk. Ufa, Institut neftekhimii i kataliza AN RB i UNTs RAN, 1994. 